\title{
Recent and Long-Term Behavior of the Brawley Fault Zone, Imperial Valley, California: An Escalation in Slip Rate?
}

\author{
by Aron J. Meltzner,* Thomas K. Rockwell, and Lewis A. Owen
}

\begin{abstract}
The Brawley fault zone (BFZ) and the Brawley Seismic Zone constitute the principal transfer zone accommodating strain between the San Andreas and Imperial faults in southernmost California. The BFZ ruptured along with the Imperial fault in the $1940 M_{\mathrm{w}} 6.9$ and the $1979 M_{\mathrm{w}} 6.4$ earthquakes, although in each case only minor slip apparently occurred on the BFZ; several other episodes of slip and creep have been documented on the BFZ historically. Until this study, it has been unclear whether the past few decades reflect average behavior of the fault. Two trenches were opened and a series of auger holes were bored across three strands of the BFZ at Harris Road to compare the amount of slip observed historically with the displacements observed in the paleoseismic record. Evidence is presented, across the westernmost strand of the BFZ and across the entire BFZ at Harris Road, to show that both the average vertical slip rate observed in modern times (since 1970) and the vertical creep rate (excluding coseismic slip) observed during the 1970s are significantly higher than the long-term average. Across the westernmost strand, the longterm vertical rate is $1.2(+1.5 /-0.5) \mathrm{mm} / \mathrm{yr}$, and the average rate since about A.D. 1710 is determined to be no greater than $2.0 \mathrm{~mm} / \mathrm{yr}$; in contrast, the average vertical rate between 1970 and 2004 across that strand was at least $4.3 \mathrm{~mm} / \mathrm{yr}$, and the $1970 \mathrm{~s}$ vertical aseismic creep rate was $10 \mathrm{~mm} / \mathrm{yr}$. Likewise, across the entire BFZ, the longterm vertical rate is $2.8(+4.1 /-1.4) \mathrm{mm} / \mathrm{yr}$, whereas the rate between 1970 and 2004 was at least $7.2 \mathrm{~mm} / \mathrm{yr}$, and the 1970s aseismic creep rate was $10 \mathrm{~mm} / \mathrm{yr}$. The long-term strike-slip rate cannot be determined across any strands of the BFZ but may be significant. In contrast to the commonly accepted higher sedimentation rates inferred for the entire Imperial Valley, we find that the average sedimentation rate on the downthrown side of the BFZ adjacent to Mesquite Basin, in the millennium preceding the onset of agricultural influences, was at most $3.5 \mathrm{~mm} / \mathrm{yr}$. Finally, a creep event occurred on the BFZ during our study in 2002 and is documented herein.
\end{abstract}

Online material: Appendices 1 and 2, trench logs, and color versions of Figures 7,8 , and 10 .

\section{Introduction}

The Brawley fault zone (BFZ) and the Brawley Seismic Zone (BSZ) constitute the principal transfer zone accommodating strain between the San Andreas and Imperial faults in southernmost California (Fig. 1). The BFZ is a complex north-south trending, west-dipping set of discontinuous fault scarps (e.g., Fig. 2) that mark the eastern boundary of Mesquite Basin, which is, in part, a transtensional graben that is bounded on the west by the northwest-trending Im-

\footnotetext{
*Present address: Division of Geological and Planetary Sciences, California Institute of Technology, Pasadena, California 91125; meltzner@ gps.caltech.edu.
}

perial fault. The BSZ is a diffuse zone of seismicity that extends north-northwest from the BFZ toward the San Andreas fault (SAF) at Bombay Beach; focal mechanisms and seismicity lineaments within the BSZ indicate that most of the earthquakes occur on left-lateral northeast-trending and right-lateral northwest-trending cross-faults (e.g., Fuis et al., 1982; Nicholson et al., 1986; P. Shearer, unpublished data). The relationship between the BFZ and the BSZ, both at the surface and at depth, is poorly understood.

Although field observations revealed that minor surface faulting occurred along several kilometers of the BFZ during the $1940 M_{\mathrm{w}} 6.9$ Imperial Valley earthquake (A. E. Sedg- 


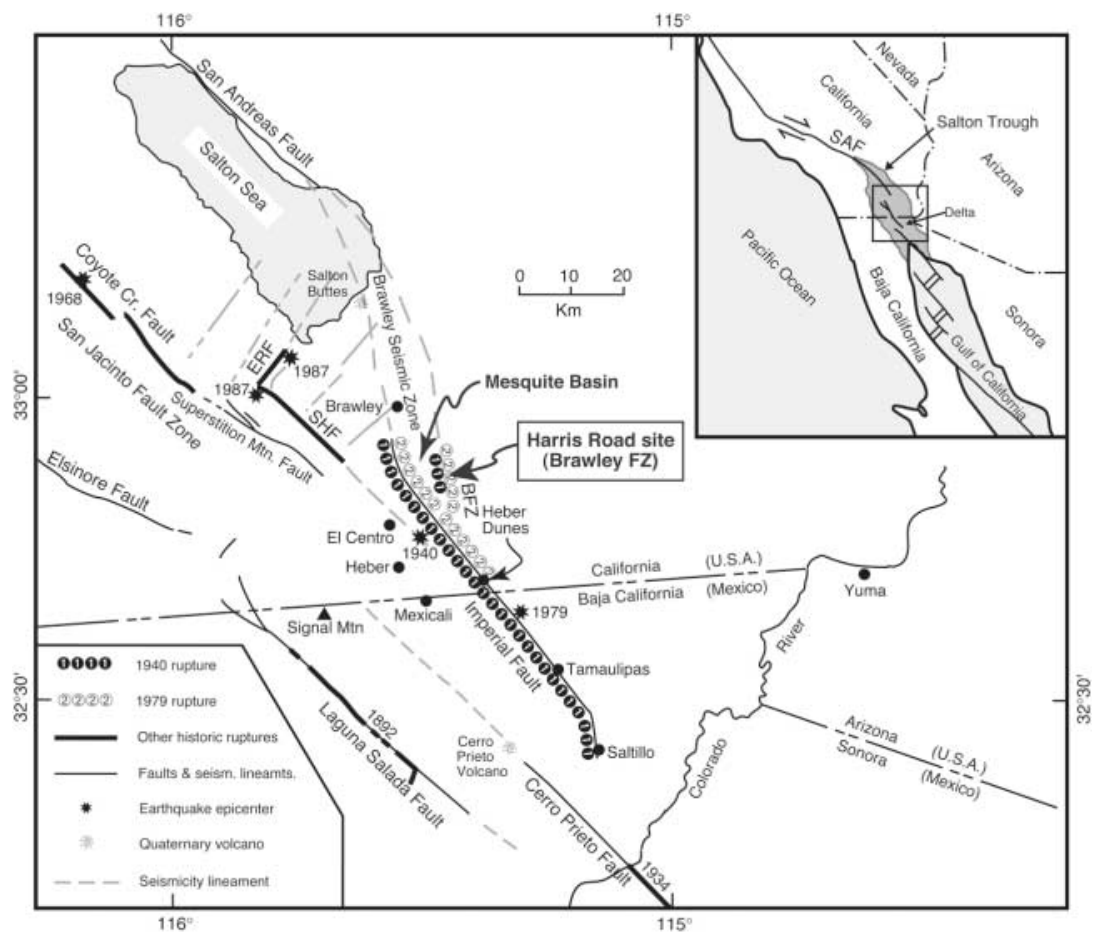

Figure 1. Generalized fault map of the southern part of the Salton Trough. Surface ruptures indicated for the $1892\left(M 7 \frac{1}{4}\right), 1934$ $\left(M_{\mathrm{L}} 7.1\right), 1940\left(M_{\mathrm{w}} 6.9\right), 1968\left(M_{\mathrm{w}} 6.5\right), 1979$ $\left(M_{\mathrm{w}} 6.4\right)$, and $1987\left(M_{\mathrm{w}} 6.2\right.$ and 6.6) earthquakes. ERF, Elmore Ranch fault; SHF, Superstition Hills fault. wick, unpublished data, 1940; Sharp, 1982), the surface expression of this fault zone was in general unrecognized until new faulting occurred during a swarm of small earthquakes in 1975 (Johnson and Hadley, 1976; Sharp, 1976, 1977). The BFZ ruptured again along with the Imperial fault during the $1979 M_{\mathrm{w}} 6.4$ earthquake; faulting along the BFZ in 1979 was more extensive than faulting documented in any of the prior historical earthquakes. (Indeed, before 1979, most authors referred to the BFZ as simply the "Brawley fault," but the number and distribution of 1979 surface ruptures led Sharp et al. [1982] to employ the term "Brawley fault zone" instead.) Slip along the BFZ does not appear to have exceeded several decimeters in any of the historical events. Despite the modern difficulty of locating fault traces within the BFZ because of ground modification for agricultural purposes, inspection of U.S. Department of Agriculture (USDA) aerial photos from 1937, when much of the ground that is traversed by the BFZ was in a more natural state, reveals that most of the historical ruptures followed clearly identifiable preexisting fault scarps or lineaments within the limits of uncertainty, typically $\pm 5 \mathrm{~m}$ (Sharp, 1977, 1982; Sharp et al., 1982). In addition to the historical coseismic ruptures just discussed, aseismic creep and triggered slip have been documented along the BFZ episodically since about 1960 (e.g., Sharp, 1976; Sharp and Lienkaemper, 1982; Louie et al., 1985). In 1975, a creepmeter was installed across the BFZ at Harris Road (see Fig. 2 for location), but problems with the creepmeter made interpretation of its record difficult (Goulty et al., 1978; Cohn et al., 1982; Louie et al., 1985); the creepmeter was abandoned in the late 1980s.

The long-term slip rate across the BFZ and/or the BSZ is poorly determined. Johnson et al. (1994) estimated 25 $\mathrm{mm} / \mathrm{yr}$ of oblique spreading across the BSZ and BFZ from geodetic data and a kinematic model of slip transfer between the southern San Andreas and Imperial faults. The Working Group on California Earthquake Probabilities (1995) assumed an overall slip rate (magnitude of the oblique slip vector) of $25 \mathrm{~mm} / \mathrm{yr}$ across the BFZ, although the basis of that rate is not explained. Smith and Sandwell (2003, 2006) assume a higher slip rate of $36 \mathrm{~mm} / \mathrm{yr}$ across the BSZ, and they predict a subsidence rate within the BSZ and Mesquite Basin of 4-8 mm/yr. Using 1931-1980 leveling data across the Imperial fault, Mesquite Basin, and the BSZ (but not across the BFZ), Larsen and Reilinger (1991) argue for a subsidence rate within Mesquite Basin of $3 \mathrm{~mm} / \mathrm{yr}$, but that rate is based on what may be flawed assumptions: they assumed that the entirety of 125 years' strain accumulation was released during the 50 years of their study period, and that there has not been ongoing subsidence since 1980. Any subsidence of the basin that occurred between 1855 and 1931 or that has occurred since 1980 would increase their calculated rate. Given either possibility, the subsidence rate of Larsen and Reilinger (1991) should only be considered as a minimum value.

Our work involved an attempt to better understand the long-term behavior of the BFZ. Unfortunately, the surface trace of the entire known BFZ has been extensively modified or destroyed for agricultural or cultural activities (see Fig. 2). Fields, typically quarter-mile squares or larger, have been leveled to facilitate their irrigation, which resulted in the removal or redistribution of considerable volumes of earth, especially from the higher side of any topographic step that lay within the boundaries of a parcel of land. This process has effectively removed 1-2 $\mathrm{m}$ of important stratigraphy and 


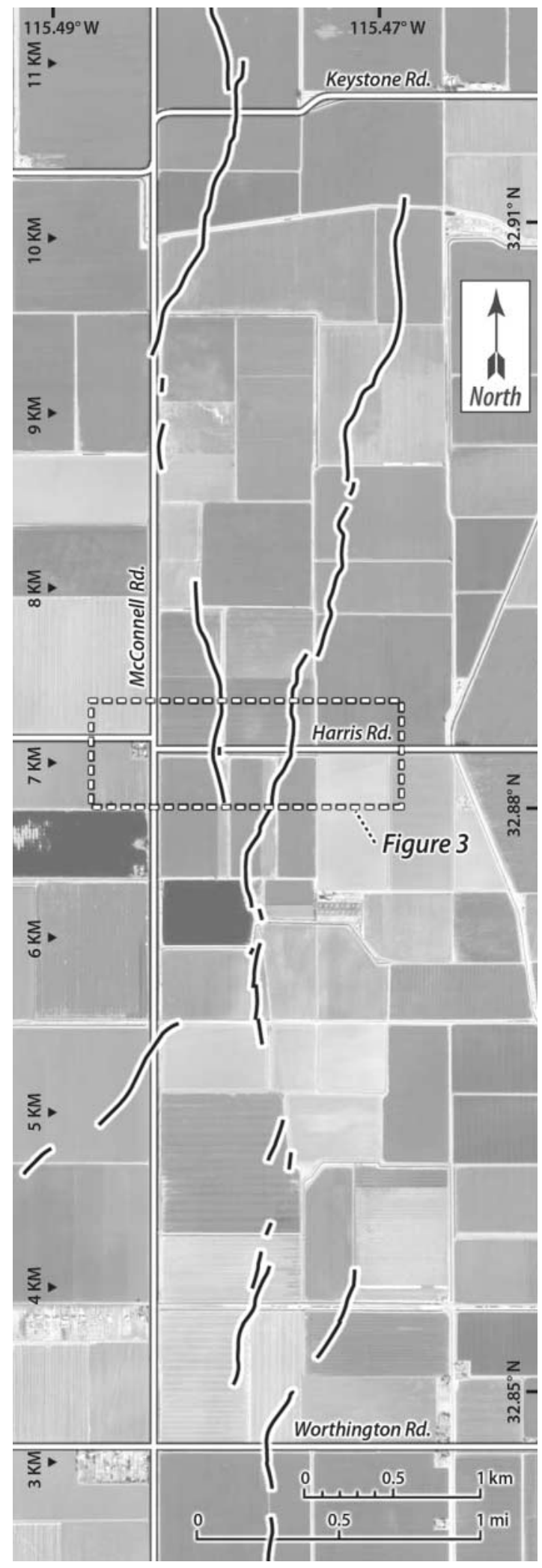

Figure 2. Portion of the 1979 rupture of the BFZ, modified from Sharp et al. (1982), superimposed on imagery from Google Earth. Kilometer marks (numbered 3-11) along the left side of the figure correspond to the distance along the reference line for the BFZ of Sharp et al. (1982). The 1979 rupture of the BFZ extended from $\mathrm{km} 1.2$ to $\mathrm{km} \mathrm{14.3.} \mathrm{The} \mathrm{entire} \mathrm{surface} \mathrm{trace}$ of the BFZ lies within agricultural fields, except where it crosses roads. The box shows the location of Figure 3. history from the upthrown side of any fault strand. Tilling of these fields with heavy machinery has disturbed the sediments and destroyed evidence of faulting even deeper into the section. In general, the roadways predate the agricultural leveling, so that the fault is generally best preserved along the dirt shoulders of the few paved roads that cross the fault. However, examination of all roads that cross the BFZ revealed problems with most of the sites: narrow shoulders in most places and buried utility cables along Worthington Road (see Fig. 2) made the south shoulder of Harris Road the only location along the known BFZ where it was feasible to excavate a trench. Nonetheless, much of the south shoulder of Harris Road had been dug up previously for the installation and routine servicing of the creepmeter, so only a small part of the shoulder within the fault zone was not completely destroyed. Furthermore, even at the Harris Road site, the 4-5 m cumulative scarp (surveyed along Harris Road in 2003) has been graded significantly to allow vehicles to drive over the scarp at high speeds. None of the dirt shoulders (along any road) are wide enough to permit 3D trenching, and there are no preserved fault-crossing features (such as stream channels) anywhere along the known BFZ that would make 3D trenching useful; this precludes any possibility of defining the amount of lateral slip in recent events. Consequently, the observations and conclusions that we were able to make at this site are very limited and leave many questions unanswered, but they appear to be the most definitive paleoseismic observations and conclusions that can be made anywhere along the BFZ at the present time.

\section{The Brawley Fault Zone at Harris Road}

Unlike the Imperial fault to the west, most of which is either a single fracture or a fairly organized set of continuous en echelon fractures, the BFZ is a complex, disjointed set of fractures that collectively define a zone of faulting up to a kilometer in width (e.g., Fig. 2; see also Sharp et al., 1982, plate 1). At Harris Road, at least three strands of the BFZ cross the pavement (Figs. 2 and 3): two strands $\sim 21 \mathrm{~m}$ apart, which lie to the west, and a third strand $\sim 400 \mathrm{~m}$ farther east. For convenience, we refer to these three strands, from west to east, respectively, as faults F1w, F1e, and F2. Likewise, we refer to the area of the south shoulder of Harris Road around strands F1w and F1e as site BFH1, and we refer to the area of the south shoulder around strand F2 as site BFH2 (see Fig. 3). In 1975, only fault F1w ruptured at the surface (Sharp, 1977); strands F1e and F2 were not identified until they slipped in 1979 (Sharp et al., 1982). The exact locations of our investigations on each fault strand are given in Table 1.

In addition to the three fault strands known prior to our study to cross Harris Road, we considered the possibility that there may be additional strands at this location. It is possible that historical ruptures have not revealed all strands of the BFZ, especially in light of the observation that not every strand ruptures in every earthquake. Similarly, because 


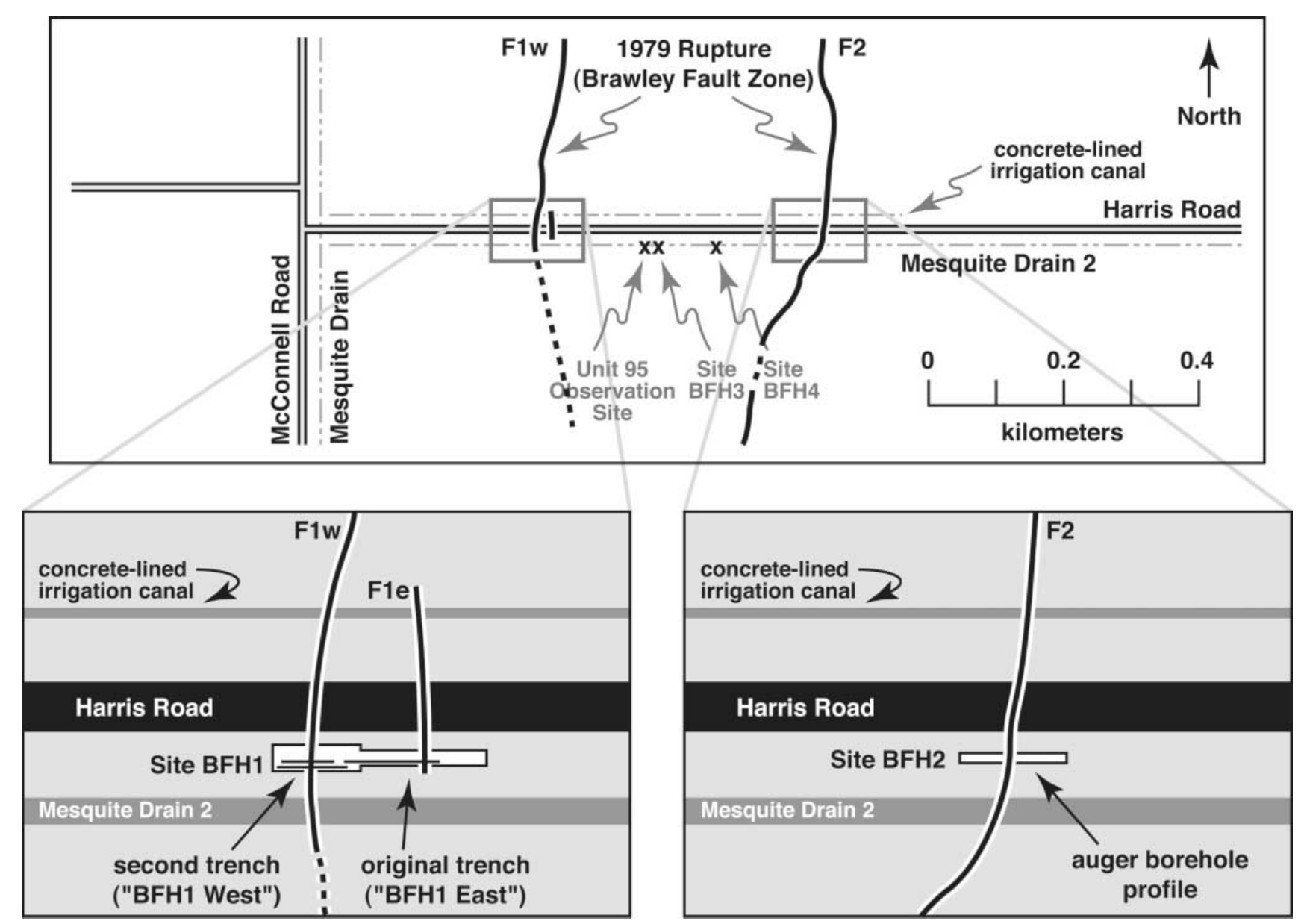

Figure 3. Map of the sites along Harris Road discussed in this article. The white box labeled "Site BFH1" is the footprint of trenches BFH1 West and BFH1 East. The three east-west trending lines within that white box correspond to the locations of the three logged trench faces: the south wall of BFH1 East, and the upper and lower benches of the south wall of BFH1 West. The upper bench was $\sim 1 \mathrm{~m}$ south of the lower bench in BFH1 West. Initially, a single slot trench was excavated across both faults, F1w and F1e. However, the initial trench collapsed within the vicinity of F1w due to the high water table. After logging the part of the initial trench that crossed F1e, we back-filled the trench and excavated the wider, shallower, benched trench (BFH1 West) across F1w. The white box labeled "Site BFH2" corresponds roughly to the location of the auger borehole profile at site $\mathrm{BFH} 2$.

Table 1

Site Locations

\begin{tabular}{|c|c|c|c|c|c|}
\hline \multirow[b]{2}{*}{$\begin{array}{c}\text { Site } \\
\text { (see Fig. 3) }\end{array}$} & \multirow[b]{2}{*}{$\begin{array}{c}\text { Fault Strand } \\
\text { (see Fig. 3) }\end{array}$} & \multicolumn{2}{|c|}{$\begin{array}{l}\text { Latitude-Longitude } \\
\quad \text { (NAD-27) }\end{array}$} & \multicolumn{2}{|c|}{$\begin{array}{l}\text { UTM Zone } 11 \\
\text { (NAD-27) }\end{array}$} \\
\hline & & $\begin{array}{l}\text { Latitude } \\
\left({ }^{\circ} \mathrm{N}\right)\end{array}$ & $\begin{array}{l}\text { Longitude } \\
\left({ }^{\circ} \mathrm{W}\right)\end{array}$ & $\begin{array}{l}\text { Northing } \\
(\mathrm{m})\end{array}$ & $\begin{array}{c}\text { Easting } \\
\text { (m) }\end{array}$ \\
\hline BFH1 West & F1w & 32.8828 & 115.4794 & $3,639,134$ & 642,248 \\
\hline BFH1 East & F1e & 32.8828 & 115.4791 & $3,639,134$ & 642,269 \\
\hline BFH2 & $\mathrm{F} 2$ & 32.8828 & 115.4748 & $3,639,139$ & 642,674 \\
\hline
\end{tabular}

Sharp (1977) could not identify every Holocene trace of the BFZ based on lineaments in 1937 aerial photos, we cannot rely on his work to guarantee that we have recognized all strands. Fortunately, most of the section is already exposed in an east-west transect that spans the width of the BFZ in the vicinity of Harris Road. Parallel to and immediately south of the south shoulder of Harris Road is Mesquite Drain 2, a 4-m-deep agricultural drainage canal with sloped earthen walls (see Fig. 3). The exposure extends from near McConnell Road, $\sim 300 \mathrm{~m}$ west of F1w, to a point $\sim 900 \mathrm{~m}$ east of F2. For perhaps $70 \%$ of this exposure, crude stratigraphy and faults are exposed in the walls of the drain (e.g., Fig. 4); in the remaining part of the drain, either the original 

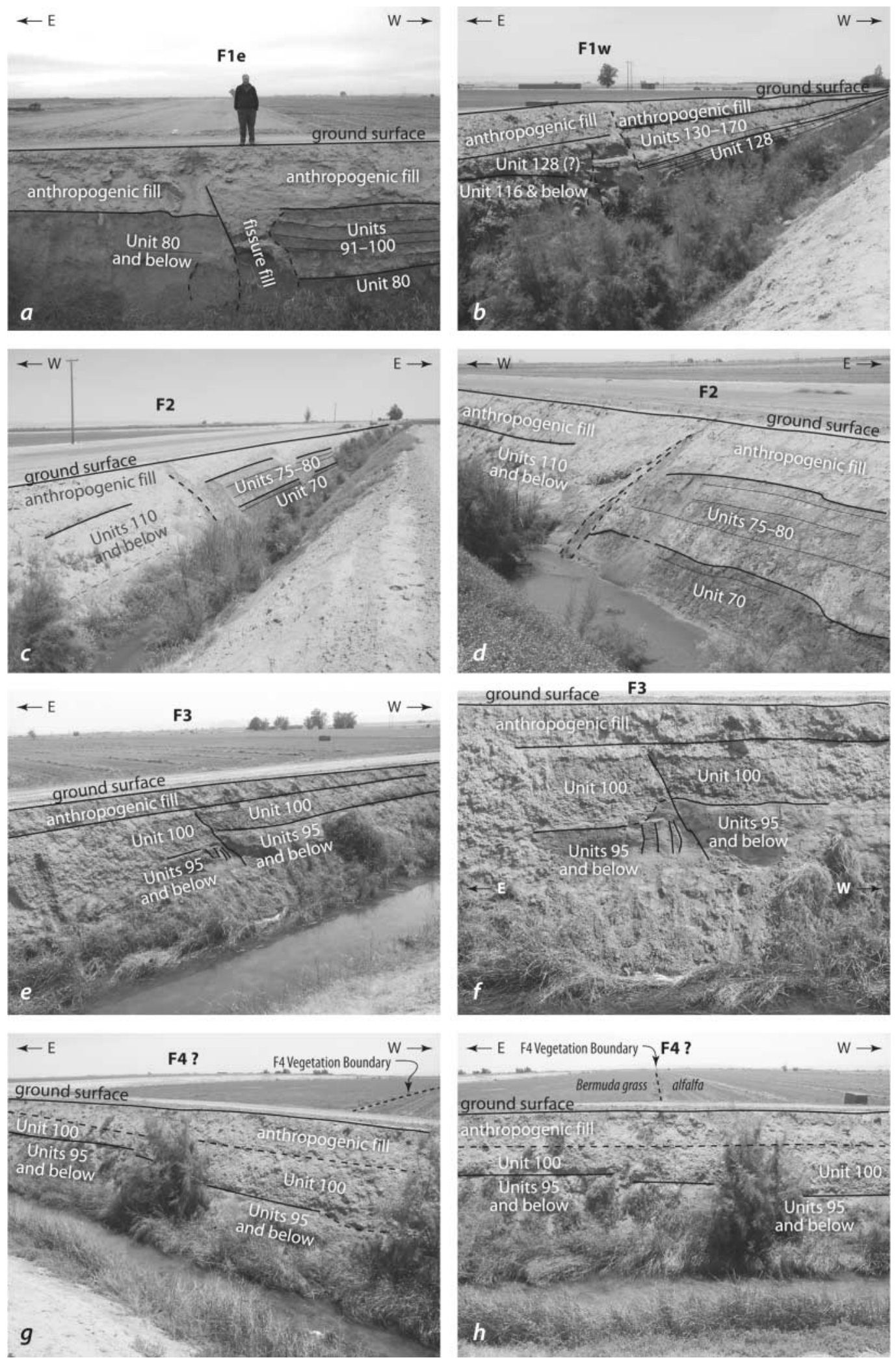

Figure 4. Photos of fault strands in the walls of Mesquite Drain 2: (a) fault F1e, looking to the south; (b) F1w, looking to the southwest; (c) F2, looking to the northeast; (d) F2, looking to the northwest; (e) F3, looking to the southwest; (f) F3, looking to the south; (g) F4, looking to the southeast; and (h) F4, looking to the south. 
stratigraphy has been replaced by fill, or it is covered by dense vegetation.

The three faults that ruptured in 1979 (F1w, F1e, and F2) are clearly evident on the drain walls: stratigraphic beds that can be followed for tens of meters or more are tilted near each of the three faults and are abruptly truncated at the faults (see Fig. 4a-d). An inspection of the remaining exposed section in the drain walls revealed nothing else comparable to these three faults, although a fourth and a possible fifth fault strand - both of which appear to be much less significant than F1w, F1e, and F2-were discovered (see Fig. 4e-h). These additional features are located at sites BFH3 and BFH4 (Fig. 3) and are herein called faults F3 and F4, respectively. Additional faults (some perhaps significant) may be present in any of the areas of the drain where the original stratigraphy is obscured, although there is no evidence to suggest that a significant amount of vertical displacement is missing.

In 1940, rupture along the (then unknown) BFZ was not well documented; in his unpublished field notes, A. E. Sedgwick described, in only general terms, a 3-km-long surface rupture in the vicinity of Harris and Ralph Roads that trended north-south and bounded the relatively downdropped basin of Mesquite Lake (Sharp, 1982); an independent observation of displacement at Keystone Road (Sharp, 1976, 1982) suggests that rupturing along the BFZ broke the surface for at least $5 \mathrm{~km}$ from north to south and that more than one strand was involved. Although it is probably safe to assume from A. E. Sedgwick's description that at least one strand crossing Harris Road ruptured in the 1940 earthquake, there is too little information to postulate which of the strands were involved.

\section{Methodology}

Initially, a single trench was excavated across fault strands F1w and F1e parallel to Harris Road, on the south shoulder of the road. In the vicinity of F1w, the trench was $\sim 3 \mathrm{~m}$ deep, but it shallowed westward. Unfortunately, because of the presence of water-saturated loose sands underlying more cohesive units near $\mathrm{F} 1 \mathrm{w}$, the trench began collapsing in the vicinity of F1w within minutes of excavating that part of the trench, despite the fact that we had already emplaced hydraulic shores for support. Because of continued but irregular irrigation of nearby fields, the level of the water table fluctuated but was consistently shallower than the base of the trench at its deeper end, near F1w; consequently, we were never able to stabilize that part of the trench long enough to clean, photograph, and log the area around F1w. Instead, we focused on logging the stable part of the trench (the area east of F1w, including the area around F1e); we then backfilled the first trench and excavated a new, shallower, wider benched trench in the vicinity of F1w. Because the first trench focused on F1e, we refer to that trench as trench BFH1 East; the second trench, which focused on F1w, is referred to as trench BFH1 West (see Fig. 3).
In BFH1 East, because of complete redundancy of information, only the south wall was logged; in BFH1 West, because the north wall of the trench within the fault zone was almost entirely disrupted from excavations related to the installation and servicing of the creepmeter, once again only the south wall was logged. In both trenches, the trench faces were gridded, etched, and photographed before being logged; the photographs were rectified to the grid and mosaicked together, and field logging was done directly on the rectified mosaicked photographs. Simplified logs are shown in Figures 5 and 6, and (E) more detailed logs, complete with the photomosaics, are available as supplemental Figures 1 and 2 in the electronic edition of BSSA.

The initial chronologic sequence of stratigraphic units was established based on the principle of superposition and the sense of slip of each strand of the BFZ known from historical observations. The age of each unit was constrained by (1) the results of ${ }^{14} \mathrm{C}$ analysis using accelerator mass spectrometry (AMS) techniques on individual pieces of detrital charcoal from various strata, (2) optically stimulated luminescence (OSL) dating of two sandy units, and (3) consideration of oral traditions of the native Cahuilla people (Modesto and Mount, 1980) and historical accounts by Spanish explorers (as discussed by Sieh and Williams, 1990) that preclude a significant lake in the Salton Trough at any time more recent than the early eighteenth century.

A brief discussion is warranted on the nature of radiocarbon analysis of detrital charcoal in the Imperial Valley. Because of the aridity of the preagricultural Imperial Valley, local natural fires were unlikely, as the vegetation was widely spread and it would have been very difficult to initiate a range fire under these conditions. There are two possible sources of charcoal in the vicinity of the BFZ site: range and forest fires in the various drainage headlands surrounding the Imperial Valley or on the Colorado Plateau, and fires by the indigenous people of the area, the Cahuilla. Both sources have potential for a large inherited age. In that $(1){ }^{14} \mathrm{C}$ dates on detrital charcoal record the date of wood growth, (2) the burning of green wood is not as likely as that of old, aged wood, and (3) there may be considerable delay between the burning of a range or forest and the subsequent transport of a piece of charcoal to its ultimate deposition site, the majority of burned wood will likely have substantially older apparent ages than the actual age of the host sediment. In addition, in the case of cooking fires prepared by the indigenous people, one might expect that the wood selected for burning would tend to be older and dryer. Therefore, a detrital charcoal sample provides only a maximum age constraint.

In addition to the trenches at site BFH1, a series of auger boreholes were dug across fault F2 at site BFH2 (see Figs. 3 and 7). Like the trenches farther west, the boreholes served to constrain the amount of vertical displacement across the fault; however, in this case, because we anticipated that the uppermost part of the section had been removed, and because we would not be able to determine an event chronol- 


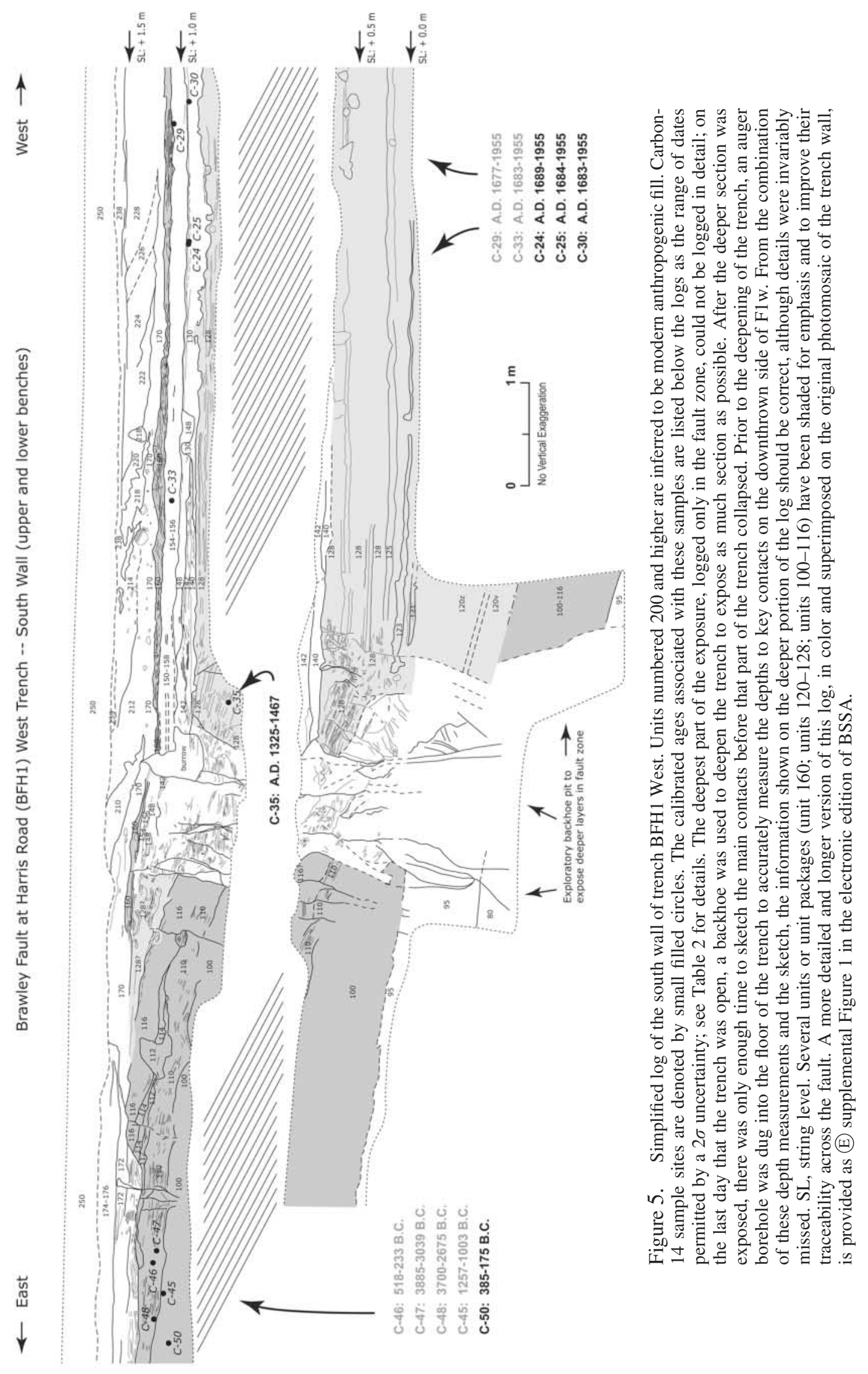




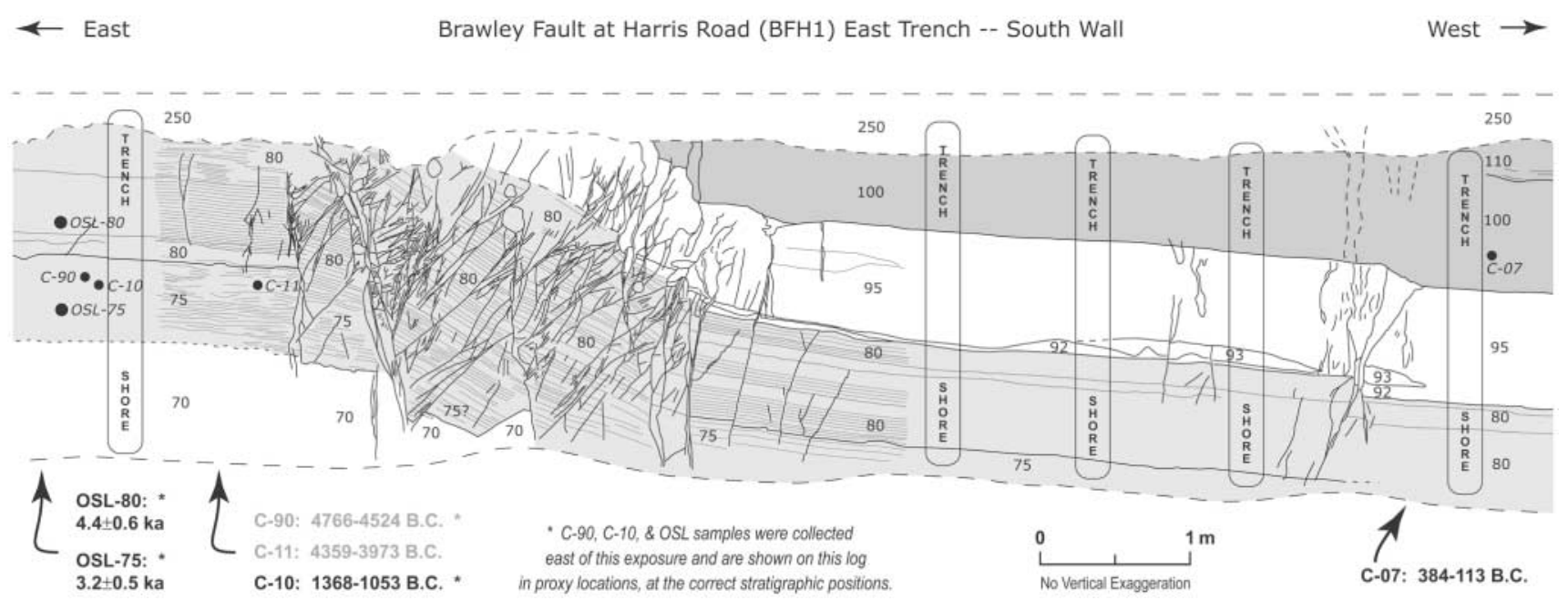

Figure 6. Simplified log of the south wall of trench BFH1 East. Units numbered 200 and higher are inferred to be modern anthropogenic fill. Carbon-14 sample sites are denoted by small filled circles; the two OSL sample locations are designated by larger filled circles. The calibrated ages associated with the Carbon-14 samples are listed below the logs as the range of dates permitted by a $2 \sigma$ uncertainty; see Table 2 for details. Two unit packages (units 100-116; units 75-80) have been shaded for emphasis and to improve their traceability across the fault. A more detailed and longer version of this log, in color and superimposed upon the original photomosaic of the trench wall, is provided as (E) supplemental Fig. 2 in the electronic edition of BSSA.

ogy for the part of the section that was missing, we realized that the limited data available at site $\mathrm{BFH} 2$ did not justify the time, effort, or cost necessary to excavate a trench and to $\log$ it in detail. The data obtained from the boreholes provide adequate constraints on the amount of vertical slip at this site.

Finally, fault F3 was examined by cleaning off its exposure in the south wall of Mesquite Drain 2; this site is referred to as site BFH3 and is discussed later in this article. Fault F4 was not examined in detail, and it is discussed only briefly.

\section{Regional Stratigraphic Setting}

Regionally, for the past millennium and presumably longer, sedimentation in the Imperial Valley has been episodic and dominated by the Colorado River. During midPleistocene time, the Colorado River built a delta across the Salton Trough from an apex near Yuma, Arizona (Fig. 1; Van de Kamp, 1973). At least five times during the past 1200 years, the Colorado River has switched from its present course (emptying southward into the Gulf of California) to flowing northward into the Salton Trough. Each time the Colorado River followed a northward course, it inundated much of the below-sea level Coachella and Imperial Valleys, producing the freshwater Lake Cahuilla that typically rose to elevations of between 9 and $13 \mathrm{~m}$ above modern sea level, the altitude of the lowest point on the Colorado River delta (Stanley, 1963, 1966; Thomas, 1963; Van de Kamp, 1973; Waters, 1983; Sieh, 1986; Sieh and Williams, 1990; Rockwell and Sieh, 1994; Gurrola and Rockwell, 1996; Thomas and Rockwell, 1996; Orgil, 2001). After filling to an elevation of $13 \mathrm{~m}$, excess input to the lake flowed south over the delta to the Gulf of California; eventually, the Colorado River would revert to a southward course, and because of the hot, dry climate, Lake Cahuilla would desiccate over about 60-70 years (Sieh and Williams, 1990).

Although five Lake Cahuilla highstands have been recognized in the past 1200 years at various sites along the shoreline, it is possible that the lake never desiccated completely between highstands; it is also possible that there were additional partial fillings of the lake in which the Colorado River did not flow northward for long enough to fill the lake entirely. During the early twentieth century, attempts to divert part of the Colorado River into the Imperial Valley for agricultural purposes resulted in the Colorado River flowing uncontrolled into the Salton Trough from 1905 to 1907. The newly named Salton Sea reached a maximum elevation of $60.2 \mathrm{~m}$ below sea level in February 1907 (Cory, 1913, p. 1412; Sykes, 1937, figure 62) before it was brought under control, and it remains at about $-70 \mathrm{~m}$ today.

Historical evidence (Sieh and Williams, 1990) and oral traditions by the indigenous Cahuilla (Modesto and Mount, 1980) preclude the possibility of a Lake Cahuilla highstand at any time since about A.D. 1680. Although the sparse early historical data might permit a short-lived partial filling of Lake Cahuilla between about 1680 and about 1825, there is no known historical or geologic evidence of any lakes larger than the twentieth-century Salton Sea since the A.D. 1680 lake, and historical observations preclude any such lake at any time since at least about A.D. 1825 (Emory, 1848; Blake, 1854, 1915; Barrows, 1900; Cory, 1913, p. 1228). In partic- 


\section{Stratigraphic East-West Profile from Auger Boreholes at Site BFH2}

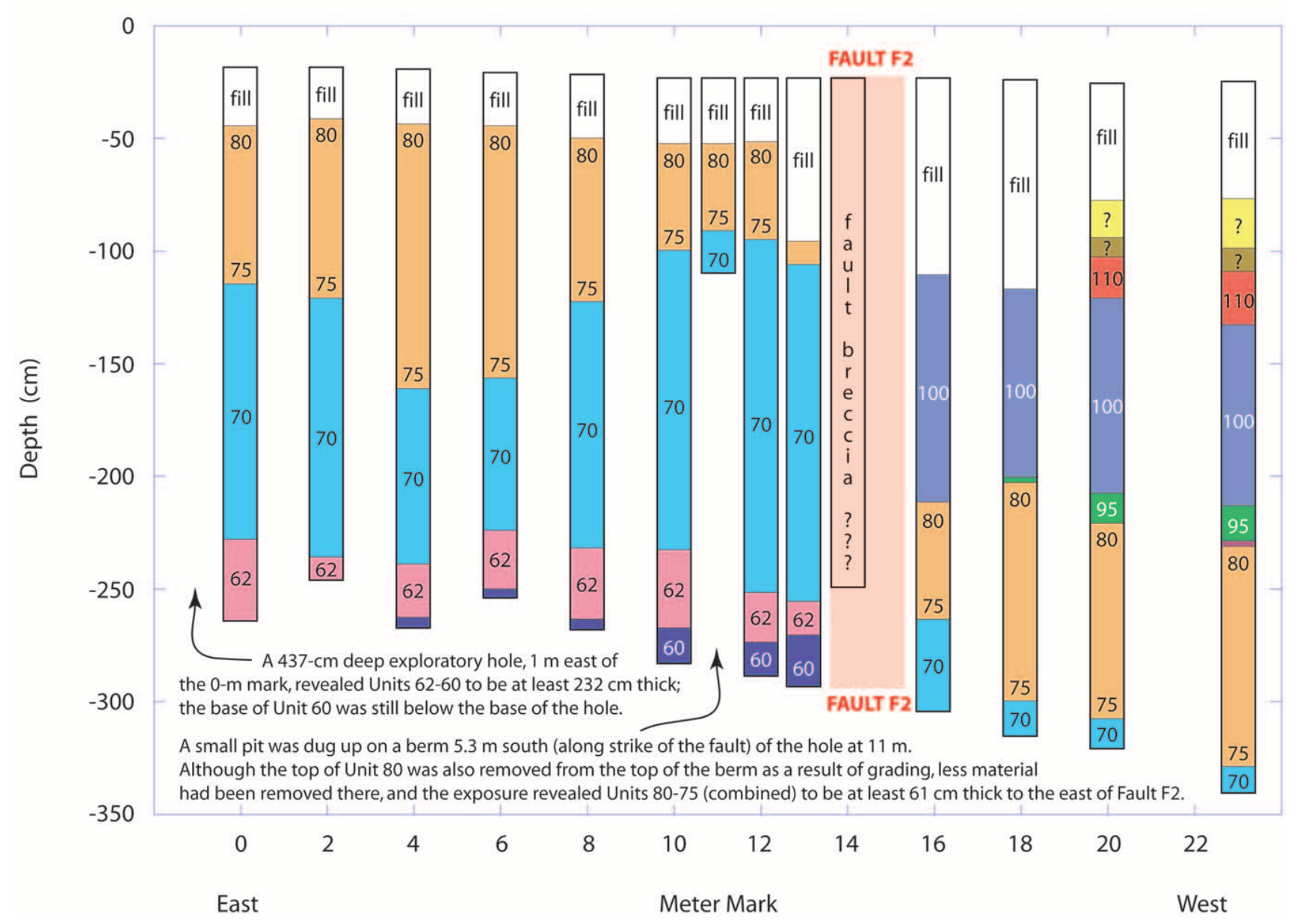

Figure 7. Stratigraphic east-west profile across fault F2 at Harris Road inferred from auger boreholes at site BFH2. As in Figure 6, two unit packages (units 100-116; units 75-80) have been shaded for emphasis and to improve their traceability across the fault. (E) A color version of this figure is available in the electronic edition of BSSA.

ular, from descriptions by Barrows (1900), Blake (1915), and Cory (1913, p. 1228) of consistently small bodies of water, and because no flood appears to have lasted more than one season or year (in contrast to the two-year flood from February 1905 to February 1907 that produced the Salton Sea), we infer that all of the short-lived nineteenth-century lakes were smaller than the twentieth-century Salton Sea.

In addition to the Salton Sea and previous partial fillings of the Salton Basin, several smaller lakes have periodically filled closed depressions elsewhere in the Imperial Valley, within the broader footprint of Lake Cahuilla. One such basin is Mesquite Basin (Figs. 1 and 8). Modern U.S. Geological Survey (USGS) topographic maps show the -140 -foot $(-42.7-\mathrm{m})$ elevation contour within Mesquite Basin as a $3.5-\mathrm{km}$ (north-south) by $2.5-\mathrm{km}$ (east-west) closed depression, whereas the higher -135 -foot $(-41.1-\mathrm{m})$ contour opens to the north. USGS (1908) shows a lake (Mesquite Lake) filling Mesquite Basin in 1908: this lake covered an area slightly larger than the -140 -foot contour, being roughly $4.25 \mathrm{~km}$ north-south by $3.0 \mathrm{~km}$ east-west.
Subaqueous deposits that have commonly been associated with Lake Cahuilla range from deltaic sands to lacustrine clays. Deltaic deposits may originate from the Colorado River, or they may have a more local source if a large storm that caused significant runoff along the basin margins occurred while Lake Cahuilla was stationary at a particular level. Lacustrine deposits may also originate locally or from the Colorado River and represent deeper water settling of suspended load. Other deposits in the Imperial Valley include meandering channel deposits (relatively low stream gradient); alluvial fans and braided-stream deposits (relatively high stream gradient); barrier beaches; and aeolian sand deposits (Van de Kamp, 1973).

\section{Trench Stratigraphy}

The BFH1 site sits at an elevation of $36.5 \mathrm{~m}$ below sea level, well below the Lake Cahuilla shoreline, but well above the 1907 highstand of the Salton Sea and the highest closed contour of Mesquite Basin. Indeed, detailed comparisons of 


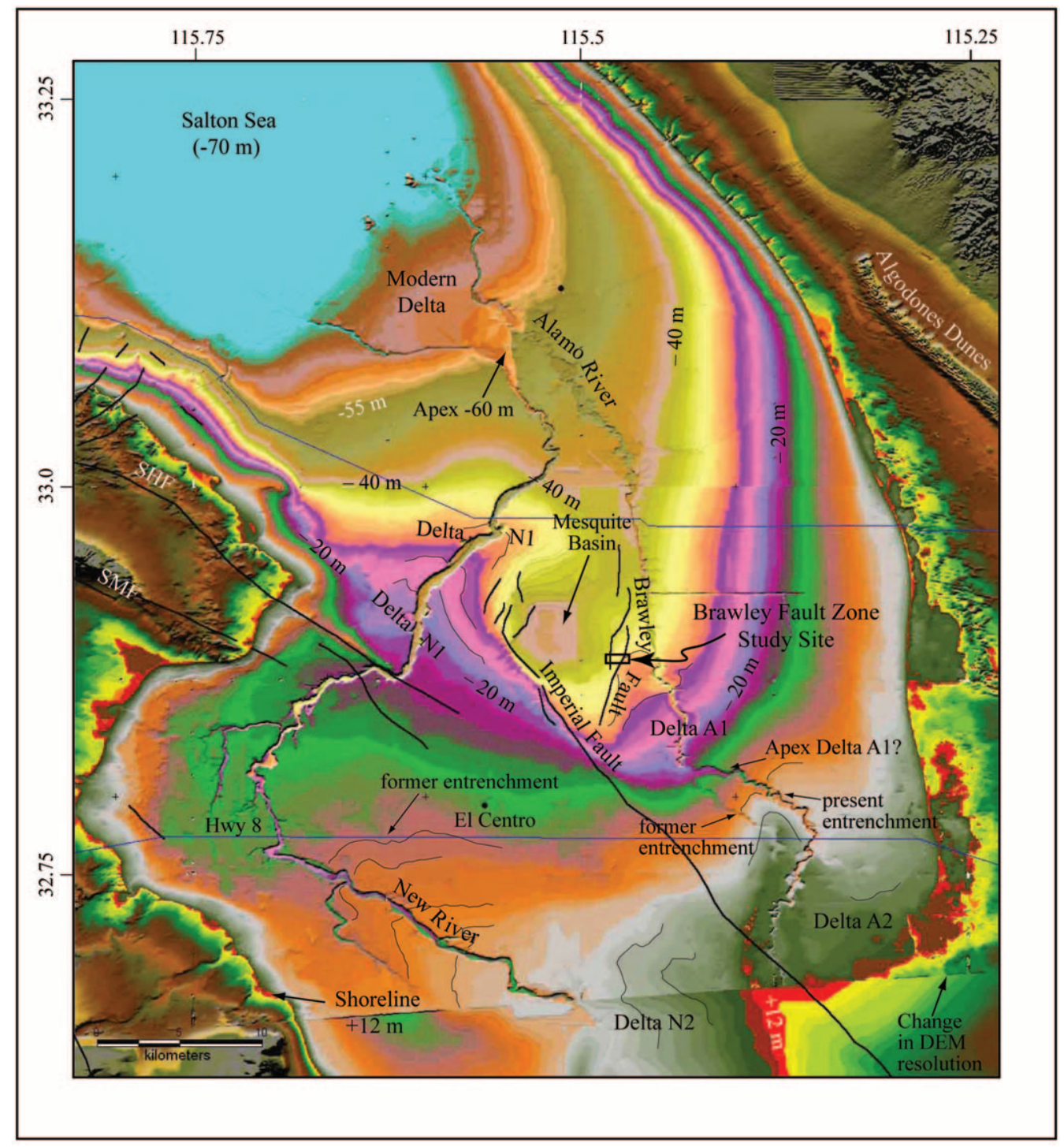

Figure 8. Southern Salton Trough deltaic system, based on DEM imagery. Color contours indicate elevation; each color band represents a 5- to 10-m change in elevation. Sections of some contours are highlighted with thin black lines for improved visibility. The band labeled " $+12 \mathrm{~m}$ " is the contour at an elevation of $12 \mathrm{~m}$ above mean sea level, which represents the highstand shoreline of Lake Cahuilla. Note the location of the modern delta, which is interpreted to have formed initially in response to the 19051907 filling of the Salton Sea; slow retreat of the lake combined with regular flow of the New and Alamo Rivers has built this modern delta that is prograding into the Salton Sea. In addition to the modern delta, four prehistoric delta lobes have been interpreted on this DEM: deltas N1 and N2 on the New River, and deltas A1 and A2 on the Alamo River. Main faults are mapped in black. SMF, Superstition Mountain fault; SHF, Superstition Hills fault. Modified from Ragona (2003). (E) A color version of this figure is available in the electronic edition of BSSA.)

USGS (1908) with modern USGS topographic maps reveal that, at its fullest and closest reach, Mesquite Lake was a number of meters lower than and at least $2 \mathrm{~km}$ away from the BFZ paleoseismic sites. Given the historical constraints on lakes in the Salton Trough, it seems reasonable to assume that any lacustrine or deltaic deposits of substantial (a few centimeters or more) thickness are at least as old as the early eighteenth century.

\section{Units 210 and Above: Anthropogenic Fill}

In the trenches at site BFH1 and in the boreholes at site $\mathrm{BFH} 2$, the uppermost layers consisted of a sequence of anthropogenic fill. These units are numbered 210 and above on the trench logs (Figs. 5 and 6, and (E) supplemental Figs. 1-2 in the electronic edition of BSSA) and are labeled "fill" on the borehole cross section (Fig. 7). A generalized strati- 
graphic column is also shown in Figure 9. The identification of these units as fill is based on several lines of evidence. Most commonly, these units are very to extremely poorly sorted, contain anthropogenic material such as Styrofoam, asphalt, or intact glass bottles, and/or contain granule-size lithic fragments with no apparent local source. (With the exception of clay pebbles found in certain sand units, grains the size of coarse sand and larger were generally not observed in the rest of the section.) In some cases, the material in these units is very loose, but in other places, these units are cemented and are harder than underlying layers. Unit 250 contains crude, roughly horizontal bedding in places, presumably a result of repeated grading. Units 210-228, which are present only in the hanging wall of $\mathrm{F} 1 \mathrm{w}$, have an intriguing downlapping geometry that is best explained as the result of bulldozing activity in which the uppermost layers of the footwall side of the fault are incrementally scraped off and pushed westward toward and over the scarp, to build up the downthrown side in laterally successive wedges; most likely, such bulldozing activity would be done to grade the scarp, so that vehicles can easily traverse it. Units $210-228$ presumably correlate with either the initial grading of Harris Road in the early part of the twentieth century (before 1937) or the regrading of the road prior to its paving in 1970.

\section{Units 140-176: Post-Lake Cahuilla Deposits}

Units 170-176 lie below units 210-250 in trench BFH1 West. Their nature is somewhat ambiguous. Although units 172-176 appear to be weakly bedded and locally overlie unit 170 , the generally massive nature of unit 170 , the similarity of unit 170 to overlying fill in terms of color and grain size (except for the lithic fragments), and the lack of a sharp upper contact make unit 170 in places difficult to distinguish from the fill; only by the fact that unit 170 is overlain by units $172-176$ do we infer that unit 170 is a bona fide nonartificial unit. On the BFH1 West trench log (Fig. 5, and (E) supplemental Fig. 1 in the electronic edition of BSSA), much of the upper contact of unit 170 west of F1w is either drawn as a dashed line or not drawn at all; in these locations, the contact is mixed and irregular, and we were unable to locate the contact.

A succession of channel-fill silty very fine to fine sands lies stratigraphically below unit 170 . The scour-and-fill geometry of units 140-160 and the small-scale cross-bedding in units 142 and 160 imply a fluvial nature for these deposits. The age of these units is relatively well constrained by an in situ 1-m-wide burn horizon near the top of underlying unit 130 (see Figs. 5 and 9, and (E) supplemental Fig. 1 in the electronic edition of BSSA). Unit 130, which will be discussed shortly, is inferred to be the uppermost portion of a sequence of deposits related to an infilling of Lake Cahuilla. Consequently, the upper contact of unit 130 marks a transition from lacustrine to fluvial facies, and it represents local emergence of the former lake bottom to subaerial conditions.
(At the time the burn horizon formed, the BFH1 site was probably near the shoreline of a gradually retreating Lake Cahuilla; it is conceivable that the burn horizon is the result of a campfire built by local Cahuilla Indians along or near the shore. It was not uncommon for fires from Cahuilla encampments to dot the shoreline of Lake Cahuilla at night [Modesto and Mount, 1980].) Calibrated two-sigma calendric ages from ${ }^{14} \mathrm{C}$ analyses of three charcoal samples from this burn horizon (see Table 2) constrain the age of all overlying units (units numbered 140 and higher) to be younger than A.D. 1689. Considering that the ground must have been subaerially exposed by the time of the burn, we further constrain units 140 and higher to be younger than the desiccation at this site of the most recent Lake Cahuilla (dated by Sieh and Williams [1990] to have had its last highstand at about A.D. 1680); using the average evaporation rate of Lake Cahuilla of $1.52 \mathrm{~m} / \mathrm{yr}$ determined by Sieh and Williams (1990), desiccation at this site would have occurred about 33 years (or more, if there was some Colorado River inflow into the lake) after the highstand.

Some or all of units 140-160 may represent known historical occasions on which Colorado River water flowed into the Salton Trough. In the years 1840, 1849, 1852, 1859, 1862, 1867, 1891, and 1905-1907, large quantities of water passed into the Salton Sea through the New and/or Alamo Rivers (Barrows, 1900; Cory, 1913, pp. 1228, 1247). (Nothing is known about floods prior to 1840 , although the period from about A.D. 1825 to 1840 apparently did not see any significant floods [Barrows, 1900]. As mentioned previously, none of the nineteenth-century infillings of the Salton Trough appear to have produced lakes that were larger than the twentieth-century Salton Sea.) Prior to 1905, the channels of the New and Alamo Rivers meandered and were comparatively shallow (Cory, 1913, p. 1410); the diversion of the Colorado River into the Salton Sea in 1905-1906 caused the rivers to incise the deep, wide channels that characterize them today (Cory, 1913, pp. 1249, 1320; Sykes, 1937, pp. 117-119). Maps from 1905 (USGS, 1907), 1908 (USGS, 1908), and 1911 (Cory, 1913, plate 46) show the Alamo and New Rivers in essentially the same courses they follow in the 1937 USDA aerial photos and today, at least near the latitude of Harris Road, from which we infer that the two rivers have not significantly altered their courses since they incised their channels (and since their flow was controlled) in 1905-1907. In contrast, a series of surveyor's maps from 1856 (Hays, 1856a,b,c,d) shows a "shallow arroyo" west of the present Alamo River but shows no channel at the present location of the Alamo River. Unfortunately, the shallow arroyo is not drawn in the vicinity of Harris Road, so the arroyo's location relative to sites BFH1 and BFH2 cannot be determined. In any case, whereas units 140160 in our trenches may represent deposition at any time between the desiccation of the A.D. 1680 lake and the beginning of incision in 1905, these units cannot plausibly be younger than A.D. 1905. 


\begin{tabular}{|c|c|c|c|c|c|c|c|}
\hline $\begin{array}{r}\text { Depositional } \\
\text { Environments }\end{array}$ & $\begin{array}{r}\text { Lithology \& } \\
\text { Sedimentary } \\
\text { Structures }\end{array}$ & $\begin{array}{r}\text { Strati- } \\
\text { graphic } \\
\text { Units }\end{array}$ & $\begin{array}{c}\text { East of } \\
\text { F1w }\end{array}$ & $\begin{array}{c}\text { West of } \\
\text { F1w }\end{array}$ & $\begin{array}{l}\text { Strati- } \\
\text { graphic } \\
\text { Units }\end{array}$ & $\begin{array}{l}\text { Lithology \& } \\
\text { Sedimentary } \\
\text { Structures }\end{array}$ & $\begin{array}{l}\text { Depositional } \\
\text { Environments }\end{array}$ \\
\hline \multirow[t]{2}{*}{ Anthropogenic Fill } & $\begin{array}{l}\text { massive, very to } \\
\text { extremely poorly } \\
\text { sorted sand with }\end{array}$ & 250 & 250 & 250 & \multirow[t]{2}{*}{$210-250$} & \multirow{2}{*}{$\begin{array}{l}\text { massive, very to } \\
\text { extremely poorly } \\
\text { sorted sand with } \\
\text { anthropogenic } \\
\text { material }\end{array}$} & \multirow[t]{2}{*}{ Anthropogenic Fill } \\
\hline & $\begin{array}{r}\text { anthropogenic } \\
\text { material }\end{array}$ & & \multirow{2}{*}{\begin{tabular}{c|c|c|}
$172-170^{2}$ \\
176
\end{tabular}} & $-----\frac{----}{210-249}$ & & & \\
\hline $\begin{array}{r}\text { Uncertain } \\
\text { (Channel-Fill / } \\
\text { Fluvial?) }\end{array}$ & $\begin{array}{l}\text { weakly bedded, } \\
\text { silty very fine to } \\
\text { fine sands }\end{array}$ & $172-176$ & & जी बे & 170 & $\begin{array}{l}\text { massive, very } \\
\text { poorly sorted sand }\end{array}$ & $\begin{array}{l}\text { Uncertain } \\
\text { (Eolian?) }\end{array}$ \\
\hline $\begin{array}{l}\text { Uncertain } \\
\text { (Eolian?) }\end{array}$ & $\begin{array}{r}\text { massive, very } \\
\text { poorly sorted sand }\end{array}$ & 170 & 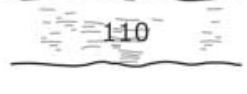 & $\frac{160}{150-158}$ & 160 & $\begin{array}{l}X \text {-bedded silty } \\
\text { very fine to find } \\
\text { sand }\end{array}$ & Fluvial \\
\hline $\begin{array}{r}\text { Deep-Water } \\
\text { Lacustrine } \\
\text { (Settling of } \\
\text { Suspended Load) }\end{array}$ & $\begin{array}{r}\text { massive reddish } \\
\text { clay }\end{array}$ & 116 & \multirow[t]{2}{*}{$\begin{array}{l}100 \\
-C-07\end{array}$} & $\begin{array}{l}-140-140,130 \\
\qquad c-35\end{array}$ & $150-158$ & $\begin{array}{l}\text { sequence of silty } \\
\text { very fine to fine } \\
\text { sands (some are } \\
\text { laminated, some } \\
\text { massive) }\end{array}$ & $\begin{array}{l}\text { Channel-Fill } \\
\text { (Fluvial?) }\end{array}$ \\
\hline Fluvial or Eolian? & $\begin{array}{r}\text { silty sands } \\
\text { (112 is laminated) }\end{array}$ & $112-114$ & & 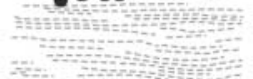 & \multirow[t]{2}{*}{$140-148$} & \multirow{2}{*}{$\begin{array}{l}\text { sequence of silty } \\
\text { very fine to fine } \\
\text { sands } \\
\text { ( } 142 \text { is } X \text {-bedded) }\end{array}$} & \multirow[t]{2}{*}{$\begin{array}{l}\text { Channel-Fill } \\
\text { (142 is Fluvial) }\end{array}$} \\
\hline $\begin{array}{r}\text { Deep-Water } \\
\text { Lacustrine }\end{array}$ & silty laminated clay & 110 & \multirow{3}{*}{95} & 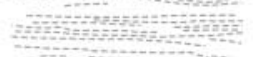 & & & \\
\hline $\begin{array}{r}\text { (Settling of } \\
\text { Suspended Load) }\end{array}$ & & & & $120-128$ & 130 & $\begin{array}{l}\text { mostly massive, } \\
\text { silty very fine to } \\
\text { fine sand with }\end{array}$ & $\begin{array}{l}\text { Near-Shore } \\
\text { Lacustrine (or } \\
\text { Beach Deposit?) }\end{array}$ \\
\hline $\begin{array}{r}\text { Deep-Water } \\
\text { Lacustrine } \\
\text { (Settling of } \\
\text { Susnended oad) }\end{array}$ & $\begin{array}{r}\text { massive reddish } \\
\text { clay }\end{array}$ & 100 & & 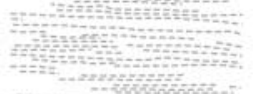 & & $\begin{array}{l}\text { soft-sediment } \\
\text { deformation }\end{array}$ & \\
\hline Suspended Load) & & & \multirow[b]{2}{*}{80} & 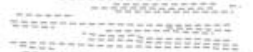 & \multirow[t]{2}{*}{$120-128$} & \multirow{2}{*}{$\begin{array}{l}\text { sequence of wavy, } \\
\text { parallel-bedded } \\
1-5-\mathrm{cm} \text { thick silty } \\
\text { clays to fine sands } \\
\text { (most beds are } \\
\text { silty very fine to } \\
\text { fine sands) }\end{array}$} & \multirow{2}{*}{$\begin{array}{l}\text { Near-Shore } \\
\text { Lacustrine } \\
\text { and Deltaic } \\
\text { Deposits }\end{array}$} \\
\hline $\begin{array}{r}\text { Near-Shore } \\
\text { Lacustrine or } \\
\text { Distal Deltaic } \\
\text { Deposits }\end{array}$ & $\begin{array}{r}\text { mostly massive } \\
\text { (faint bedding in } \\
\text { places) silty very } \\
\text { fine sand }\end{array}$ & 95 & & 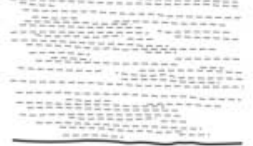 & & & \\
\hline $\begin{array}{r}\text { Overbank-Type } \\
\text { Deposit (?) } \\
\text { within depressions }\end{array}$ & $\begin{array}{l}\text { silty lenses (?) } \\
\text { just west of F1e }\end{array}$ & $91-93$ & & $=116$ & \multirow[t]{2}{*}{116} & \multirow{2}{*}{$\begin{array}{l}\text { massive reddish } \\
\text { clay }\end{array}$} & \multirow{2}{*}{$\begin{array}{l}\text { Deep-Water } \\
\text { Lacustrine } \\
\text { (Settling of } \\
\text { Suspended Load) }\end{array}$} \\
\hline \multirow{2}{*}{$\begin{array}{r}\text { Deltaic } \\
\text { (Channel-Fill ?) }\end{array}$} & planar-laminated & & \multirow{2}{*}{$\frac{c-10}{75}$} & $\frac{112-114}{110}$ & & & \\
\hline & $\begin{array}{l}\text { planar-laminated } \\
\text { fine sand }\end{array}$ & 80 & & & * 112-114 & $\begin{array}{l}\text { silty sands } \\
\text { (112 is laminated) }\end{array}$ & Fluvial or Eolian? \\
\hline $\begin{array}{r}\text { Fluvial } \\
\text { (or Deltaic?) }\end{array}$ & $\begin{array}{r}\text { X-bedded silty } \\
\text { very fine to fine } \\
\text { sand }\end{array}$ & 75 & -------- & 100 & 110 & silty laminated clay & $\begin{array}{l}\text { Deep-Water } \\
\text { Lacustrine } \\
\text { (Settling of } \\
\text { Suspended Load) }\end{array}$ \\
\hline $\begin{array}{l}\text { Lacustrine } \\
\text { (Settling of }\end{array}$ & $\begin{array}{r}\text { coarsening } \\
\text { upwards to a }\end{array}$ & 10 & & & 100 & massive reddish & Deep-Water \\
\hline Suspended Load) & clayey silt & & 70 & $\begin{array}{l}95 \\
\text { (lowest unit exposed) }\end{array}$ & & & $\begin{array}{l}\text { (Settling of } \\
\text { Suspended Load) }\end{array}$ \\
\hline $\begin{array}{r}\text { Deep-Water } \\
\text { Lacustrine } \\
\text { (Settling of } \\
\text { Suspended Load) }\end{array}$ & $\begin{array}{r}\text { massive sticky } \\
\text { clay }\end{array}$ & 62 & & $\Phi-0 \mathrm{~cm}$ & 95 & $\begin{array}{l}\text { mostly massive } \\
\text { (faint bedding in } \\
\text { places) silty very } \\
\text { fine sand }\end{array}$ & $\begin{array}{l}\text { Near-Shore } \\
\text { Lacustrine or } \\
\text { Distal Deltaic } \\
\text { Deposits }\end{array}$ \\
\hline $\begin{array}{r}\text { Deep-Water } \\
\text { Lacustrine } \\
\text { (Settling of }\end{array}$ & laminated clay & 60 & 62 & 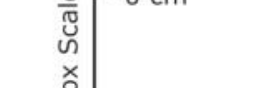 & & & \\
\hline Suspended Load) & & & 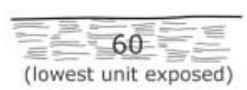 & 은 & $\begin{array}{l}\text { * Units } 11 \\
\text { the dee } \\
\text { The pre }\end{array}$ & $\begin{array}{l}114 \text { could not be clearly } \\
\text { ackhoe pit (see BFH1 W } \\
\text { cee of these units west o }\end{array}$ & $\begin{array}{l}\text { entified west of F1w in } \\
\text { st trench log, Fig. 5). } \\
\text { F1w is inferred. }\end{array}$ \\
\hline
\end{tabular}

Sample C-24 in Unit 130 constrains stratigraphically higher deposits to be younger than A.D. 1689. Sample C-35 in Unit 128 constrains stratigraphically higher deposits to be younger than A.D. 1325. Sample C-07 in Unit 100 constrains stratigraphically higher deposits to be younger than 384 B.C. Sample C-10 in Unit 75 constrains stratigraphically higher deposits to be younger than 1368 B.C.

Figure 9. Generalized stratigraphy and chronology of the sediments exposed in the BFZ at the Harris Road sites. 
Table 2

Radiocarbon Ages Derived from Detrital Charcoal Samples

\begin{tabular}{|c|c|c|c|c|c|}
\hline Sample* & $\begin{array}{l}\text { Stratigraphic } \\
\text { Unit }^{\dagger}\end{array}$ & $\delta^{13} \mathrm{C}^{\ddagger}$ & $\begin{array}{c}\text { Uncalibrated }{ }^{14} \mathrm{C} \text { Age, } \\
\text { Years B.P. }{ }^{\S}\end{array}$ & $\begin{array}{c}\text { Calibrated Calendric } \\
2 \sigma \text { Max-Min Date Range }\end{array}$ & Probability ${ }^{\#}$ \\
\hline BFH-C-36 & 170 & -25 & $37,900 \pm 400$ & too old for calibration curve & - \\
\hline BFH-C-29 & 156 & -25 & $105 \pm 40$ & $\begin{array}{l}\text { A.D. } 1677-1762 \\
\text { A.D. } 1803-1938 \\
\text { A.D. } 1946-1955\end{array}$ & $\begin{array}{l}0.328 \\
0.645 \\
0.026\end{array}$ \\
\hline BFH-C-33 & $154-156$ & -25 & $70 \pm 40$ & $\begin{array}{l}\text { A.D. } 1683-1733 \\
\text { A.D. } 1807-1929 \\
\text { A.D. } 1947-1955\end{array}$ & $\begin{array}{l}0.261 \\
0.698 \\
0.041\end{array}$ \\
\hline BFH-C-24 & 130 & -25 & $80 \pm 30$ & $\begin{array}{l}\text { A.D. } 1689-1729 \\
\text { A.D. } 1810-1922 \\
\text { A.D. } 1948-1955\end{array}$ & $\begin{array}{l}0.249 \\
0.712 \\
0.039\end{array}$ \\
\hline BFH-C-25 & 130 & -25 & $65 \pm 40$ & $\begin{array}{l}\text { A.D. } 1684-1732 \\
\text { A.D. } 1808-1927 \\
\text { A.D. } 1947-1955\end{array}$ & $\begin{array}{l}0.252 \\
0.703 \\
0.045\end{array}$ \\
\hline BFH-C-30 & 130 & -25 & $70 \pm 40$ & $\begin{array}{l}\text { A.D. } 1683-1733 \\
\text { A.D. } 1807-1929 \\
\text { A.D. } 1947-1955\end{array}$ & $\begin{array}{l}0.261 \\
0.698 \\
0.041\end{array}$ \\
\hline BFH-C-35 & 128 & -25 & $505 \pm 40$ & $\begin{array}{l}\text { A.D. } 1325-1349 \\
\text { A.D. } 1391-1455 \\
\text { A.D. } 1456-1463 \\
\text { A.D. } 1464-1467\end{array}$ & $\begin{array}{l}0.099 \\
0.888 \\
0.010 \\
0.003\end{array}$ \\
\hline BFH-C-46 & 110 & -25 & $2,335 \pm 40$ & $\begin{array}{l}\text { 518-435 B.C. } \\
\text { 435-356 B.C. } \\
\text { 288-257 B.C. } \\
247-233 \text { B.C. }\end{array}$ & $\begin{array}{l}0.201 \\
0.696 \\
0.084 \\
0.018\end{array}$ \\
\hline BFH-C-47 & 110 & -25 & $4,730 \pm 140$ & $\begin{array}{l}\text { 3885-3885 B.C. } \\
\text { 3795-3088 B.C. } \\
\text { 3059-3039 B.C. }\end{array}$ & $\begin{array}{l}0.000 \\
0.993 \\
0.006\end{array}$ \\
\hline BFH-C-48 & 110 & -25 & $4,530 \pm 200$ & $\begin{array}{l}\text { 3700-2855 B.C. } \\
2855-2844 \text { B.C. } \\
2815-2675 \text { B.C. }\end{array}$ & $\begin{array}{l}0.957 \\
0.002 \\
0.041\end{array}$ \\
\hline BFH-C-45 & 100 & -25 & $2,920 \pm 35$ & $\begin{array}{l}1257-1236 \text { B.C. } \\
1214-1135 \text { B.C. } \\
1135-1003 \text { B.C. }\end{array}$ & $\begin{array}{l}0.048 \\
0.312 \\
0.640\end{array}$ \\
\hline BFH-C-50 & 100 & -25 & $2,215 \pm 45$ & 385-175 B.C. & 1.000 \\
\hline $\begin{array}{l}\text { BFH-C-07 } \\
.11 \mathrm{mgC}\end{array}$ & 100 & -25 & $2,190 \pm 50$ & $\begin{array}{l}\text { 384-145 B.C. } \\
145-113 \text { B.C. }\end{array}$ & $\begin{array}{l}0.952 \\
0.048\end{array}$ \\
\hline BFH-C-90 & 75 & -25 & $5,775 \pm 40$ & $\begin{array}{l}\text { 4766-4758 B.C. } \\
4716-4524 \text { B.C. }\end{array}$ & $\begin{array}{l}0.016 \\
0.984\end{array}$ \\
\hline BFH-C-11 & 75 & -25 & $5,360 \pm 100$ & 4359-3973 B.C. & 1.000 \\
\hline BFH-C-10 & 75 & -25 & $2,975 \pm 30$ & $\begin{array}{l}1368-1361 \text { B.C. } \\
1315-1111 \text { B.C. } \\
1099-1078 \text { B.C. } \\
1060-1053 \text { B.C. }\end{array}$ & $\begin{array}{l}0.008 \\
0.960 \\
0.023 \\
0.009\end{array}$ \\
\hline
\end{tabular}

*All samples were single fragments of charcoal.

${ }^{\dagger}$ High-numbered units are above (younger than) low-numbered units.

${ }^{*} \delta^{13} \mathrm{C}$ values are the assumed values according to Stuiver and Polach (1977).

${ }^{8}$ The quoted ${ }^{14} \mathrm{C}$ age is in radiocarbon years using the Libby half-life of 5568 years and following the conventions of Stuiver and Polach (1977). Sample preparation backgrounds have been subtracted, based on measurements of samples of ${ }^{14} \mathrm{C}$-free coal. Backgrounds were scaled relative to sample size.

${ }^{9}$ Uncorrected ${ }^{14} \mathrm{C}$ ages were dendrochronologically calibrated using Calib Rev 4.3 based on Stuiver and Reimer (1993) and Stuiver et al. (1998).

${ }^{\#}$ Relative area under $2 \sigma$ probability distribution. 
Units 75-130: Most Recent Lake Cahuilla and Older Deposits

Units $120-130$ are inferred to represent near-shore lacustrine and deltaic deposits. The nature of unit 130 itself is ambiguous; it is a silty very fine to fine sand, and it is mostly massive, although faint irregular laminations can be observed in some locations, especially near its upper and lower contacts. The lower contact of unit 130 is highly irregular, and there appear to be signs of soft-sediment deformation of this contact after deposition of some or all of unit 130. Possible interpretations of this deformation are that it results from shaking-induced liquefaction or that it is a set of load structures that result from footsteps in the soft sediment near the shore, but the cause is not clear. Units 120-128 consist of a sequence of wavy, parallel-bedded 1- to 5-cm-thick silty clays to fine sands. Most of units 120-128 are silty very fine to fine sands, but a few beds stand out: unit 125 is a sandy silt (more silt, less sand); unit 123 is a silty clay; unit 121 is a very fine to fine sand (very little silt); and unit $120 \mathrm{w}$ is a reduced silty sand.

The bulk of units $100-116$ is inferred to represent deeper-water lacustrine facies. Units 100 and 116 are both massive reddish clays that break apart in peds and which do not have prominent laminations. They are inferred to be the product of settling of suspended load in quiet lacustrine environments. Unit 110 is similar to units 100 and 116, but it is siltier and laminated; the laminations cause this unit to appear "ledgy" in the trench wall when it dries. Unit 110 was probably formed under similar conditions as units 100 and 116 , but its coarser nature indicates that unit 110 was probably formed closer to shore or closer to a sediment source such as a river delta. Under the classification of Van de Kamp (1973), units 100, 110, and 116 would be considered lutite. Interbedded with units 100, 110, and 116 are units 112, 113, and 114, which are coarser-grained sandy deposits. Unit 112 is laminated. The exact nature of these deposits is ambiguous, but they might represent a period of subaerial exposure and deposition (possibly fluvial deposition) in between infillings of Lake Cahuilla, and would in that case represent desiccation to below the $-37-\mathrm{m}$ level.

Units 75-95 are interpreted to be fluvial and/or deltaic in origin. Starting at the base of this sequence and going up in section, unit 75 is a small-scale cross-bedded silty very fine to fine sand. The upper and lower contacts of unit 75 are roughly planar, except in the fault zones and in other isolated areas; the lower contact of unit 75 is gradational over $\sim 10 \mathrm{~cm}$. East of fault F2, unit 75 appears to have locally filled channels in the underlying material; this channeling was evident a few meters east of F2 in the auger borehole profile (see Fig. 7), and it is also apparent several meters farther south and east in the exposure in Mesquite Drain 2 (see Fig. 4d). It is not known whether these two exposures represent one or more channels; regardless, the channeling likely represents contemporaneous headward erosion into the upthrown block of fault F2. In the immediate vicinity of this channel, clay pebbles (which are inferred to be rip-up clasts from upstream) are present in the lower part of this unit; these clay pebbles were not observed elsewhere in the unit. Unit 80 is a pervasively planar-laminated fine sand with alternating light and dark laminations. Where original bedding is preserved, the upper and lower contacts of unit 80 are typically planar. Units $91-93$ are thin beds that appear to pinch out eastward toward fault F1e, possibly indicating that they were deposited over pre-existing topography that was not present at the time of deposition of unit 80 . Unit 95 is generally massive, comprising silty very fine sand, although faint internal bedding is detectable in places. West of fault F1w, in the uppermost $\sim 20 \mathrm{~cm}$ of unit 95 , the very fine sand is interlayered with clay. In the vicinity of site BFH1, the upper contact of unit 95 is typically planar, and the lower contact is roughly planar; however unit 95 pinches out eastward toward fault F2, which leads to the inference that unit 95, like units 91-93, was deposited over pre-existing topography. We infer that units 75-95 represent fluvial or deltaic facies; the channelized base of unit 75 just east of F2 is inferred to be either a channel within the delta or a small channel within the broader river channel.

Units 75-95 are also consistent with Van de Kamp's (1973) description of meandering channel facies. From bottom to top, a complete fining upward sequence consists of active channel fill, partial-abandonment fill, and abandoned channel fill (Meckel, 1972). According to Van de Kamp's (1973) observations, active channel fill deposits of the Alamo River are typically fine to very fine grained, well to very well sorted, horizontally laminated or medium-scale cross-bedded sands, commonly with a basal lag of clay pebble clasts; partial-abandonment channel fill is characterized by well sorted, very fine sands that are laminated or locally small-scale cross-bedded, and by laminated and ripplebedded silts with interlayered clays; abandoned channel fill is composed of laminated clay and silt. In this sequence, the abandoned channel fill is commonly indistinguishable from lacustrine silt and clay due to its similar character and the intimate association of the two (Van de Kamp, 1973). In the Harris Road section, units 75-80 are consistent with active channel fill, unit 95 is consistent with partial-abandonment channel fill, and part of unit 100 may represent abandoned channel fill, which in this case would be indistinguishable from the overlying lacustrine deposits.

The ages of units $75-130$ are constrained by radiocarbon analysis of several detrital charcoal samples and by OSL dating of two sediment samples (see Tables 2 and 3; Figs. 5, 6, and 9; and (E) supplemental Figs. 1 and 2 in the electronic edition of BSSA). Unfortunately, many of the samples used for ${ }^{14} \mathrm{C}$ dating give ages that are out of sequence; the most plausible explanation for this is that the samples have a variable and sometimes significant inherited age prior to deposition. Consequently, the maximum age of any unit is best constrained by the youngest sample in any underlying units. As such, the calibrated two-sigma calendric age of sample C-35 in unit 128 constrains unit 130 and the upper part of 
Table 3

Ages Derived from OSL Samples*

\begin{tabular}{|c|c|c|c|c|c|c|c|c|c|}
\hline Sample No.\# & $\begin{array}{l}\text { Particle } \\
\text { Size } \\
(\mu \mathrm{m})\end{array}$ & $\begin{array}{c}{[\mathrm{U}]^{\dagger}} \\
(\mathrm{ppm})\end{array}$ & $\begin{array}{l}{[\mathrm{Th}]^{\dagger}} \\
(\mathrm{ppm})\end{array}$ & $\begin{array}{l}{[\mathrm{K}]^{\dagger}} \\
(\%)\end{array}$ & $\begin{array}{l}{[\mathrm{Rb}]^{\dagger}} \\
(\mathrm{ppm})\end{array}$ & $\begin{array}{c}\text { Dose Rate } \\
(\mathrm{Gy} / \mathrm{ka})\end{array}$ & $\begin{array}{c}\text { Mean of } 3 \\
\text { Dose Rates } \\
(\mathrm{Gy} / \mathrm{ka})\end{array}$ & $\begin{array}{l}\text { Mean } D_{E}^{\S} \\
\text { (Gy) }\end{array}$ & $\begin{array}{l}\mathrm{Age}^{\mathrm{II}} \\
(\mathrm{ka})\end{array}$ \\
\hline OSL-75a & $90-125$ & 1.68 & 7.64 & 2.0 & 81.6 & $2.82 \pm 0.18$ & & & \\
\hline OSL-75b & $90-125$ & 2.19 & 7.60 & 2.1 & 76.2 & $3.04 \pm 0.20$ & & & \\
\hline OSL-75c & $90-125$ & 2.26 & 7.77 & 2.1 & 80.2 & $3.05 \pm 0.20$ & $2.97 \pm 0.33$ & $9.38 \pm 1.49$ & $3.2 \pm 0.5$ \\
\hline OSL-80a & $90-125$ & 0.95 & 4.48 & 1.5 & 60.8 & $2.07 \pm 0.14$ & & & \\
\hline OSL-80b & $90-125$ & 1.28 & 5.14 & 1.8 & 60.9 & $2.38 \pm 0.16$ & & & \\
\hline OSL-80c & $90-125$ & 1.69 & 5.34 & 1.8 & 62.9 & $2.53 \pm 0.17$ & $2.33 \pm 0.27$ & $10.20 \pm 1.78$ & $4.4 \pm 0.6$ \\
\hline
\end{tabular}

*Summary of OSL dating results from quartz extracted from sediment matrices, radioisotope concentrations, total dose rates, equivalent dose $\left(D_{E}\right)$ estimates, and optical stimulated luminescence ages.

${ }^{\#}$ Three subsamples (a, b, c) were taken from each sample (OSL-75, OSL-80).

'Elemental concentrations from NAA of whole sediment measured at Becquerel Laboratories, Lucas Heights, Australia. Uncertainty taken as $\pm 10 \%$.

${ }^{*}$ Estimated fractional water content from whole sediment (Aitken, 1998), with uncertainty taken as $5 \pm 5 \%$. Estimated contribution to dose rate from cosmic rays calculated according to Prescott and Stephan (1982) and Prescott and Hutton (1994). Uncertainty taken as $\pm 10 \%$. Total dose rate from beta, gamma, and cosmic components. Beta attenuation factors for U, Th, and K compositions incorporating grain-size factors from Mejdahl (1979). Beta attenuation factor for $\mathrm{Rb}$ arbitrarily taken as 0.75 (cf. Adamiec and Aitken, 1998). Factors utilized to convert elemental concentrations to beta and gamma dose rates from Adamiec and Aitken (1998) and beta and gamma components attenuated for moisture content.

${ }^{\S}$ Mean equivalent dose $\left(D_{E}\right)$ determined from replicated single-aliquot regenerative-dose (SAR; Murray and Wintle, 2000) runs. Error is $1 \sigma$ standard deviation.

${ }^{\mathbb{T}}$ Errors incorporate dose-rate errors and $1 \sigma$ standard errors (i.e., $\sigma_{n-1} / n^{1 / 2}$ ) incorporating error from beta source estimated at about $\pm 5 \%$ for the mean equivalent dose $\left(D_{E}\right)$.

unit 128 to be younger than A.D. 1325; to the extent that units 120-128 were deposited in rapid succession, these units cannot be much older than the uppermost part of unit 128. Similarly, samples C-07 and C-50 in unit 100 constrain the upper part of unit 100 and all stratigraphically higher units to be younger than 384 B.C., and sample C-10 in unit 75 constrains the uppermost part of unit 75 and higher units to be younger than 1368 B.C.

Although the charcoal samples provide a maximum age for all overlying units, it is not clear from the radiocarbon analysis alone how tight the maximum-age constraints are, because it is possible that all of the charcoal samples in units 75-128 have an inherited age of several hundred to several thousand years. Samples from units 75 and 80 were independently dated using OSL methods (see Table 3). Assuming our interpretation that these deposits are fluvial or deltaic in origin is correct, these deposits should be reasonable candidates for OSL dating, because individual sand grains should likely have been exposed to light and "reset" at the time of or in the hours before their deposition. Unfortunately, although the OSL age of unit 75 appears to be reasonable $(3.2 \pm 0.5 \mathrm{ka})$, the two ages are reversed, and the OSL age of unit 80 is about 1000 years too old: unit 80, which is stratigraphically higher than unit 75 , has an OSL age that is about 1000 years older than that of unit 75 and likewise about 1000 years older than permitted by the radiocarbon analysis discussed previously. The old age might be attributed to partial bleaching problems. If we ignore the OSL result from unit 80 but assume that the result from unit 75 is correct within its stated uncertainty, then it appears that radiocarbon sample $\mathrm{C}-10$ in unit 75 did not have a significant inherited age, and that the maximum age inferred from the radiocarbon analysis for the uppermost part of unit 75 and higher is robust.

Given the apparent age of units 75 and higher, and given the observation that the only lacustrine facies within units 75 and higher occurred exclusively in units 100-130 (and in the uppermost part of unit 95), we infer that units 100-130 represent all of the lakes within the past 3200 years that filled the Salton Trough to an elevation of $-36 \mathrm{~m}$ or higher, although the infilling of the earliest of those lakes may be represented in part by units 75-95. Although there is evidence for minor scouring and local erosion of some of the lake deposits of the past few thousand years, there is no evidence for widespread erosion (i.e., scouring that is wider than the length of the trench) of significant portions of the lake deposits. Furthermore, we consider it unlikely for there to have been significant erosion on the downdropped side of the BFZ.

We know from trenches at the Lake Cahuilla shoreline (13 $\mathrm{m}$ above sea level) that there were four Lake Cahuilla highstands in fairly rapid succession between A.D. 1440 and approximately A.D. 1680 (Gurrola and Rockwell, 1996). Nearby, at sea level, there is evidence for four distinct lakes between A.D. 1630 and about A.D. 1680 (Orgil, 2001). Orgil (2001) argued that the three most recent lakes at the sea level site correspond one-for-one with the three most recent highstands at the shoreline site of Gurrola and Rockwell (1996), whereas the fourth lake back at the sea level site represents a partial filling (the lake appears to have peaked at an elevation slightly above sea level but below $+13 \mathrm{~m}$, and therefore this partial filling would not be seen in the record at the shoreline site) that was followed by brief desiccation (to below sea level) and eventual refilling to the +13 -m shoreline. 
The fourth lake back at the shoreline site of Gurrola and Rockwell (1996), which is dated at A.D. 1440-1640, does not appear to be present at the sea level site, because it is older than a major erosional event that removed part of the sedimentary record there (Orgil, 2001). In the time between the most recent series of lakes, the lake would not have had sufficient time to desiccate completely; if in this period, however, the lake level fluctuated on a scale of several decades between $13 \mathrm{~m}$ above sea level and $\sim 30 \mathrm{~m}$ below sea level (which is possible assuming the vertical evaporation rate of $1.52 \mathrm{~m} / \mathrm{yr}$ determined by Sieh and Williams [1990]), one might expect a depositional sequence similar to that observed in units 120-128. In light of this information, and given the observation that there are no younger lacustrine deposits in the trench, we propose that units 120-130 represent, at least in part, the lakes between A.D. 1440 and about 1680.

In addition to the four Lake Cahuilla highstands identified at the shoreline between A.D. 1440 and about A.D. 1680, Gurrola and Rockwell (1996) identified a highstand at A.D. $887+77 /-70$. If units $100-130$ represent all of the lakes within the past 3200 years that filled the Salton Trough to an elevation of $-36 \mathrm{~m}$ or higher, then the A.D. $887+77 /$ -70 lake must be included in those units. Consequently, the A.D. 817-964 date range represents the minimum age of the base of unit 100 .

An inspection of a digital elevation model (DEM) (Fig. 8) reveals that the BFH1 site sits on the margin of a prehistoric Alamo River delta (delta A1). Delta A1, and its presumably contemporaneous counterpart on the New River (delta N1), extend northward and downward from an apex at an elevation of $\sim 19 \mathrm{~m}$ below sea level; Ragona (2003) interpreted that these bodies prograded northward from a temporally stable $-19-\mathrm{m}$ Lake Cahuilla paleoshoreline. The timing of these deltas are not well constrained, although they must predate the A.D. 1680 highstand: oral traditions by the native Cahuilla (Modesto and Mount, 1980) and historical accounts (Emory, 1848; Blake, 1854, 1915; Barrows, 1900; Cory, 1913, p. 1228; Sieh and Williams, 1990) collectively preclude a significant still stand at this level at any time since the A.D. 1680 lake. The delta must also be young enough to still be recognizable in the present topography. Any or all of units 120-130 may be associated with this delta; alternatively, to the extent that units 75-95 are deltaic in origin, they may be associated with the delta instead, which would imply units $120-130$ are associated with a subtler feature that is not discernible in the present geomorphology.

If Units 100-116 represent multiple lake highstands, it is not well understood why little nonlacustrine deposition is preserved between units 100 and 116. Possible explanations include: (1) during that time, Lake Cahuilla rarely or never desiccated fully, leaving the BFH1 site submerged for most of the past few thousand years; (2) the site was subaerially exposed for extensive periods, but little subaerial deposition occurred in that time; or (3) significant subaerial deposition occurred between late Holocene highstands of Lake Cahui- 1la, but significant unrecognized erosion erased almost all of this record. Native Cahuilla legends suggest that typical conditions in the Salton Trough are those with no lake: numerous villages dotted the below-sea level desert floor in the footprint of Lake Cahuilla, but occasionally and suddenly, water would return and force these clans to relocate to the foothills and remain there for several generations (Barrows, 1900; Modesto and Mount, 1980, chapter 3). These legends tend to preclude explanation 1.

\section{Units 70 and Below}

Below unit 75 lies unit 70, which is a clayey silt that grades reversely down to a silty clay. Unit 62 is a massive sticky clay, similar to unit 100; although this unit was observed only well below the water table, the minimal porosity of this unit caused it to have a relatively low water content. Unit 60 is similar to unit 62 , but unit 60 is finely and pervasively laminated and appears to have even lower water content. Because only the upper part of unit 70 was exposed in the trenches, and because the lower part of unit 70 and all lower units were revealed only in the auger boreholes, little is known about the stratification of these units. Furthermore, no samples (with which to date the lower units) were collected from below unit 75 , so we have no maximum age for these units.

\section{Missing (Removed) Strata}

Although there is no evidence of a missing section on the downthrown (west) side or immediately east of fault $\mathrm{F} 1 \mathrm{w}$, it is clear that some layers or portions thereof have been removed (both by natural channelization and by anthropogenic means) between $\mathrm{F} 1 \mathrm{w}$ and $\mathrm{F} 1 \mathrm{e}$, and a significant part of the section is missing east of F1e. At site $\mathrm{BFH} 2$, a significant part of the section is missing east of F2, although most if not all of the section appears to be intact immediately west of F2. Of particular concern are the observations that the uppermost part of unit 80 and higher units were removed from the upthrown sides of both faults F1e and F2, apparently when the respective scarps were planed off at some point in the historical period.

We will attempt to estimate the thickness of the missing section east of F1e, but we do not have sufficient information to reasonably estimate how much is missing east of F2. Based on measurements of the thickness of unit 100 where it appears to be entirely preserved-in the lower bench of trench BFH1 West, in trench BFH1 East, and in the two westernmost boreholes (those at meter marks 20 and 23) at site $\mathrm{BFH} 2$ - unit 100 appears to have a uniform original thickness of $\sim 80 \mathrm{~cm}$. Indeed, we should expect a fairly uniform thickness for unit 100; considering that unit 100 predominantly represents settling of suspended load under a deep water column, and that unit 100 would be draped over any pre-existing topography, there should not be a significant difference in the thickness of unit 100 over several 
hundred meters laterally, or over a difference in elevation of at most a few meters (a small fraction of the total height of the water column). For unit 95, we cannot automatically assume a uniform thickness; however, in an exposure on the wall of Mesquite Drain 2 located 145 m east of F1e or $17 \mathrm{~m}$ west of F3 (see "Unit 95 Observation Site," Fig. 3), unit 95 is $91 \mathrm{~cm}$ thick, which is slightly thicker than to the west of F1e; for our best estimate of its thickness, we will assume unit 95 maintains a $75-\mathrm{cm}$ thickness over the 4-m-wide fault zone at F1e.

The irregular contact between unit 80 and the overlying artificial fill east of F1e suggests that an unknown amount of unit 80 was removed from the upthrown side of F1e. Immediately west of F1e, unit 80 has a fairly uniform thickness of $\sim 70 \mathrm{~cm}$; immediately east of F1e, unit 80 appears to have been at least $90 \mathrm{~cm}$ thick, based on the maximum observed preserved thickness. The greater thickness of unit 80 on the upthrown side of F1e in trench BFH1 East suggests (1) that there was probably little (if any) topographic relief across F1e at the time of deposition of Unit 80, (2) that there has probably been significant strike-slip displacement across F1e since deposition of Unit 80, and (c) that there is probably not much of unit 80 missing from the east side of F1e. Hence, our best estimate of the original thickness of unit 80 east of F1e is the minimum estimate, $90 \mathrm{~cm}$.

\section{A Lower Sedimentation Rate?}

In the course of our work, we recognized one possible inconsistency between our findings and a commonly held belief about the Holocene sedimentation rate for the Imperial Valley. In his 1973 article, Van de Kamp asserts that Holocene deposits in the Imperial Valley are roughly 60 to $100 \mathrm{~m}$ thick, although the limited data in his article do not appear to support such an estimate. A thorough search of published literature has not revealed a revised estimate of that thickness. Our findings indicate either that the rate of sedimentation varied considerably with time or that Van de Kamp's estimate is too high.

We will first focus on the downdropped (west) side of fault $\mathrm{F} 1 \mathrm{w}$, where the sedimentation rate has necessarily been higher than elsewhere in our trenches across the BFZ. Here, the base of unit 100 is $\sim 3.5 \mathrm{~m}$ below the base of the historical fill. Using A.D. $887+77 /-70$ as the minimum age of the base of unit 100, the 3.5-m thickness of units 100170 provides a maximum constraint on the amount of deposition at this site between about A.D. 887 and the beginning of agriculture in the Imperial Valley in the early twentieth century. Of course, it is possible that there were other lakes prior to the A.D. 887 lake but younger than units 75-80; Gurrola and Rockwell (1996) identified one other Lake Cahuilla highstand at the shoreline, some time between the A.D. 887 lake and 4674 B.C. If that is the case, then the $3.5 \mathrm{~m}$ of section in consideration represents a longer time span of deposition than $\sim 1000$ years, and it suggests a correspondingly slower sedimentation rate. Nonetheless, using our conservative estimate for the past 1000 years, if the rate of $3.5 \mathrm{~m}$ of sedimentation per thousand years is appropriate for the entire Holocene, then the total thickness of Holocene deposits at this site is at most $35 \mathrm{~m}$; this is much lower than Van de Kamp's (1973) range of 60-100 m for the entire Imperial Valley. Two possible interpretations of this inconsistency are that the sedimentation rate was much higher in the early- to mid-Holocene than during the past 1000 years, or that Van de Kamp's (1973) estimate is too high. Alternatively, we cannot preclude the possibility that all of our dates (radiocarbon and OSL) are too old, that the A.D. 887 $+77 /-70$ lake of Gurrola and Rockwell (1996) is represented at the Harris Road sites by units 60-62, and that units 100-170 are considerably younger.

Different authors (e.g., Keller, 1979; Larsen and Reilinger, 1991) have suggested a purely tectonic origin to Mesquite Basin based on the dip components of slip along the Brawley and northern Imperial faults and on the thickness of the sedimentary sequence in the vicinity of the basin. In light of this commonly held belief, one might expect that the rate of sedimentation observed on the downthrown side of fault F1w in the Mesquite Basin would be among the highest rates anywhere in the Imperial Valley. As Ragona (2003) points out, however, tectonic subsidence between the Brawley and Imperial faults may not be as significant as previously considered. Analysis of a DEM of the Imperial Valley reveals that presumably contemporaneous deltas of the New and Alamo Rivers (deltas N1 and A1, respectively) surround Mesquite Basin, leaving the basin as a topographic low between the surrounding delta lobes (Ragona, 2003; Fig. 8). Ragona (2003) suggested that both tectonic subsidence of Mesquite Basin and comparatively high amounts of recent sedimentation just beyond its margins have contributed considerably to the basin's present relief. Our observation of a low sedimentation rate west of the BFZ in Mesquite Basin supports Ragona's (2003) argument.

A similar exercise immediately east of $\mathrm{F} 1 \mathrm{w}$, where little, if any, section was lost due to grading, reveals that only $\sim 2.5 \mathrm{~m}$ of sediments have been deposited in the 1000-year (or longer) period between the deposition of the base of unit 100 and the beginning of agricultural influence in sedimentation patterns.

\section{Historical Observations of Slip across the BFZ at Harris Road}

A temporally and spatially complex history of aseismic creep, coseismic slip, and postseismic deformation has been documented along the BFZ since the 18 May 1940 Imperial Valley earthquake, although the quality and quantity of the documentation has varied tremendously in those 66 years. Specifically, very little is known about creep prior to August 1970. A summary of the observations of or inferences about creep and slip across the BFZ at Harris Road since 1940 is presented in (E) Appendix 1 in the electronic edition of BSSA; the information is listed more succinctly in Table 4. 
Table 4

Discrete Historical Creep along the Brawley Fault Zone at Harris Road*

\begin{tabular}{|c|c|c|c|c|}
\hline \multirow[b]{2}{*}{ Time Window } & \multicolumn{3}{|c|}{ Fault Strand } & \multirow[b]{2}{*}{ References } \\
\hline & F1w & F1e & $\mathrm{F} 2$ & \\
\hline May 1940 earthquake & \multicolumn{3}{|c|}{ Probable displacement on F1w, F1e, and/or F2; details unknown } & \\
\hline $\begin{array}{l}\text { After } 1940 \text { earthquake; prior to } \\
\text { Aug } 1970 \text { paving of Harris Road }\end{array}$ & \multicolumn{3}{|c|}{ Probable displacement on F1w, F1e, and/or F2; details unknown } & \\
\hline Aug 1970 to 5 Feb 1975 & $\begin{array}{l}8 \mathrm{~cm} \mathrm{ESU} \\
\sim 0 \mathrm{~cm} \mathrm{RL}\end{array}$ & 0 & $\sim 0 \mathrm{~cm}^{\ddagger}$ & 1 \\
\hline 5 Feb 1975 to 25 Oct 1977 & 0 & 0 & $\sim 0 \mathrm{~cm}^{*}$ & 1,2 \\
\hline 25 Oct 1977 to 17 Jan 1979 & $\begin{array}{l}\sim 0.8 \mathrm{~cm} \mathrm{ESU} \\
\sim 0 \mathrm{~cm} \mathrm{RL}\end{array}$ & $\begin{array}{l}\sim 0.1 \mathrm{~cm} \mathrm{ESU} \\
\sim 0 \mathrm{~cm} \mathrm{RL}\end{array}$ & $\sim 0 \mathrm{~cm}^{\ddagger}$ & 2 \\
\hline 17 Jan to 19 Apr 1979 & 0 & 0 & $\sim 0 \mathrm{~cm}^{\ddagger}$ & 2 \\
\hline $\begin{array}{l}19 \text { Apr to } 17 \text { Oct } 1979 \\
\text { (presumed to be primarily coseismic slip) }\end{array}$ & $\begin{array}{l}5.1 \mathrm{~cm} \mathrm{ESU} \\
7.3 \mathrm{~cm} \mathrm{RL}\end{array}$ & $\begin{array}{l}2.5 \mathrm{~cm} \mathrm{ESU} \\
\sim 0 \mathrm{~cm} \mathrm{RL}\end{array}$ & $\begin{array}{l}\sim 7 \mathrm{~cm} \mathrm{ESU} \\
\sim 0 \mathrm{~cm} \mathrm{RL}\end{array}$ & 2,3 \\
\hline 17 Oct to 30 Dec 1979 & 0 & 0 & 0 & 2 \\
\hline 30 Dec 1979 to 6 Jan 1981 & amount unknown & amount unknown & amount unknown & \\
\hline 6 Jan to 30 Apr 1981 & 0 & 0 & 0 & 4 \\
\hline 30 Apr 1981 to 12 Feb 1984 & amount unknown & amount unknown & amount unknown & \\
\hline 12 Feb 1984 to 13 Apr 1988 & $\sim 0 \mathrm{~cm}^{\S}$ & $\sim 0 \mathrm{~cm}^{\S}$ & $\sim 0 \mathrm{~cm}^{\S}$ & 5,6 \\
\hline 13 Apr 1988 to $\sim 16$ Oct 1999 & amount unknown & amount unknown & amount unknown & \\
\hline$\sim 16$ Oct to 10 Nov 1999 & no obvious creep ${ }^{\text {qI }}$ & no obvious creep ${ }^{\text {TI }}$ & no obvious creep ${ }^{\text {TI }}$ & 7 \\
\hline 10 Nov 1999 to 1 Apr 2002 & amount unknown & amount unknown & amount unknown & \\
\hline 1 Apr to 2 Nov 2002 & no obvious creep ${ }^{\mathbb{I}}$ & no obvious creep ${ }^{\mathbb{I}}$ & no obvious creep ${ }^{\text {II }}$ & 8 \\
\hline 2 Nov to 14 Dec 2002 & $\begin{array}{l}\sim 0.6 \mathrm{~cm} \mathrm{ESU} \\
\sim 0.4 \mathrm{~cm} \mathrm{RL}\end{array}$ & no obvious creep ${ }^{\text {II }}$ & no obvious creep ${ }^{\text {II }}$ & 8 \\
\hline 14 Dec 2002 to 24 Apr 2004 & no obvious creep ${ }^{\mathbb{I}}$ & no obvious creep ${ }^{\mathbb{T}}$ & no obvious creep II $^{\text {I }}$ & 8 \\
\hline
\end{tabular}

*This table lists only discrete slip at the surface along each fault strand, i.e., displacements measured within $5 \mathrm{~m}$ or less of each respective fault. Additional tilting (over an aperture of tens of meters) was regularly documented but is not reported in this table. See original sources for more information. ESU, east-side-up vertical displacement; RL, right-lateral displacement.

†References: 1. Sharp (1976); 2. Sharp and Lienkaemper (1982); 3. Sharp et al. (1982); 4. Sharp et al. (1986); 5. Sharp (1989); 6. McGill et al. (1989); 7. Rymer et al. (2002); 8. This work.

${ }^{\ddagger}$ No cracks were observed across F2 before October 1979, although the leveling line did not extend as far as F2 and it is not clear how much creep might have occurred across F2 between August 1970 and October 1979 while evading notice by scientists. If anything, said amount is likely very small.

${ }^{\S}$ The leveling profiles clearly show broad tilting during this interval. Roughly $1-2 \mathrm{~mm}$ of discrete slip across each fault strand may have occurred but would be at the limit of resolution of the leveling lines.

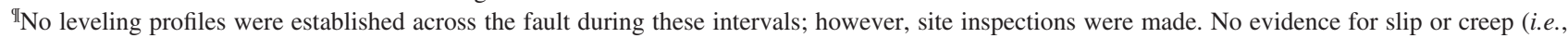
no fresh cracking) was found during these inspections. Very small amounts of shallow slip or creep are permissible and would not necessarily have been observed.

The amount of movement documented during that time should only be construed as a minimum, even since 1970 . During a 9-year period from 1970 to 1979, when creep and slip were best documented at this site, there was roughly $9 \mathrm{~cm}$ of aseismic creep across the fault zone at Harris Road. This creep appears to have been purely dip-slip (down to the west), excludes any broad off-fault tilting that may have occurred, and excludes slip presumed to be coseismic (attributable to the 1979 earthquake). Many authors (e.g., Sharp and Lienkaemper, 1982) have pondered whether the $1 \mathrm{~cm} /$ yr creep rate documented in the 1970s is representative of the long-term average; other than the subsidence and slip rates mentioned in the introduction, none of which are based on data across the BFZ proper, no studies to date have explored this question further.

\section{Slip History, Based on Paleoseismic Evidence}

One of the common goals of paleoseismology is to ascertain details (such as the size and timing) of individual past events on a fault. Unfortunately, this is not possible at the BFZ site. The main reasons for this limitation are geological. First, because an apparently significant amount of slip along the BFZ is accommodated by creep or in smallslip events (such as 1975 or 1979), individual faulting events do not always produce fissures, colluvial wedges, or other common signatures of event horizons, and fault strands do not always have abrupt upward terminations, even at known event horizons; these issues make it potentially difficult to recognize all event horizons. Second, because the event recurrence time might be short relative to the average periodicity of sedimentation (especially in light of the number of earthquakes and creep episodes in the twentieth century alone), it is highly probable that multiple events are recorded at some event horizons. Third, in lacustrine environments in which deposition is achieved solely by settling of suspended load, any scarps that form are typically preserved, and growth strata are typically not deposited unless deposition becomes dominated by fluvial, deltaic, or other processes; 
this leads to the possibility that event horizons within clay units might not be recognizable, and that it might not be possible to distinguish between a single (comparatively large) event at the end of a lake highstand and a single event or multiple smaller events at different times within the lake's history. And finally, because the BFZ is complex and we cannot guarantee that we have identified every strand, it is possible that some events did not break the strands we have examined. In addition to these geological limitations, anthropogenic modification of the ground surface (and, in particular, removal of portions of the stratigraphic section at certain faults) has entirely removed some information from the geological record.

Instead of attempting to recognize individual events, we will attempt to determine the amount of vertical displacement that occurred on the faults during key stratigraphic intervals. Considering that both creep and coseismic slip at this site during the historical period were predominantly in the dip direction (Table 4), we will compare the vertical displacements seen in the paleoseismic record with those documented during the historical period. To the extent that vertical displacement is proportional to total slip at both timescales, this can be a useful comparison.

\section{Slip across Fault F1w}

As mentioned previously, we constrain units 140-160 to predate the historical incision of the modern channel of the Alamo River in A.D. 1905-1907. Thus, the extent to which units 140-160 are displaced across fault strand F1w represents the maximum amount of displacement that could have occurred as discrete surface slip across F1w since 1905. (Some of the measured displacement could have occurred prior to 1905. This value therefore would define the maximum displacement.) Unfortunately, a large burrow in the fault zone in the main exposure of trench BFH1 West destroyed the faulting relationships and displacements recorded in units 140-160 in that exposure (see Fig. 5, and (E) supplemental Fig. 1 in the electronic edition of BSSA), but the wall was cut back and relogged in the vicinity of the fault zone; the log of the new cut, which was $\sim 40 \mathrm{~cm}$ south of the original cut, is shown in (E) supplemental Fig. 1 in the electronic edition of BSSA. Using the log of the new cut, we "retro-deformed" the two sides of the fault to construct a restored section in which units $140-160$ project across the fault with minimal displacements (see Fig. 10). We find that "undoing" $8.7 \pm 0.8 \mathrm{~cm}$ of vertical displacement provides the most reasonable restoration of units 140-160 across fault F1w, although changes in the thickness of certain units across the fault suggest that there was also a significant amount of strike slip. Surprisingly, the apparent vertical displacement in the trench wall since 1905 is less than the amount of dip slip across F1w $(\sim 14 \mathrm{~cm})$ measured at Harris Road between 1970 and 1979. The likely explanation for this apparent paradox is that some of the displacement measured in the leveling profiles along Harris Road (Sharp and
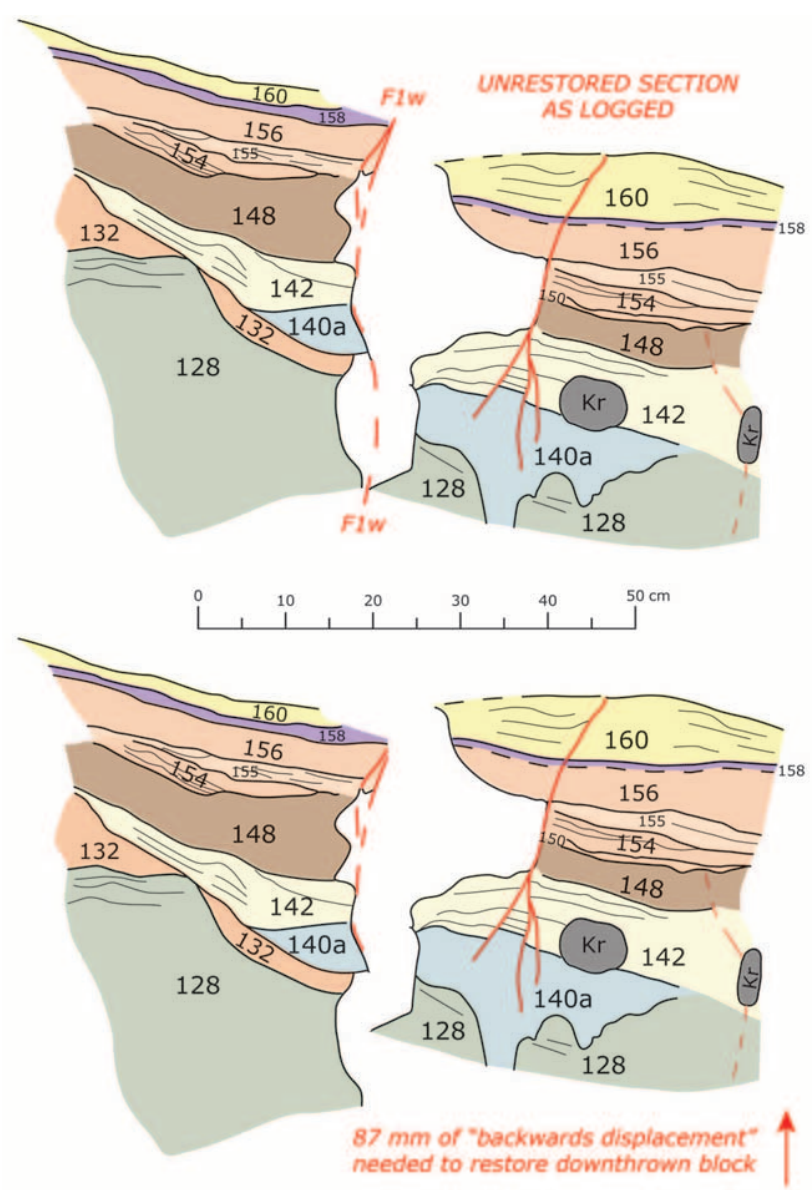

Figure 10. Retrodeformation of uppermost stratigraphy across fault F1w. (Top) Present configuration. (Bottom) Best-fitting restoration of the section to its position immediately after deposition of unit 160. A vertical displacement of $87 \mathrm{~mm}$ has been "undone"; we find that "undoing" a vertical displacement of anywhere in the range $87 \pm 8 \mathrm{~mm}$ provides a reasonable restoration, but discrete vertical displacements that are larger or smaller than that range yield less plausible restorations. (E) A color version of this figure is available in the electronic edition of BSSA.)

Lienkaemper, 1982) was accommodated as tilting or warping across the fault zone in the trench wall, $\sim 7 \mathrm{~m}$ to the south. Fault zone F1w itself-if defined by the locus of dense fractures-is about $2 \mathrm{~m}$ wide, although in the uppermost meter of the trench most of the discrete slip appears confined to a single plane. The strata in the trench dip westward in the vicinity of the fault zone, and although some of the dip almost certainly is primary (i.e., growth strata deposited against a scarp), tilting due to fault slip at depth and/ or distributed strain over several meters is likely. If the entirety of the vertical relief of units 158 and 160 over a 5 -meter aperture centered on fault F1w is a result of postdepositional tilting (i.e., if units 158 and 160 were horizontal when originally deposited across $\mathrm{F} 1 \mathrm{w}$ ), then the amount of vertical separation across the F1w fault zone since 1905 could not exceed $\sim 30 \mathrm{~cm}$. 
It is apparent, then, that at least half of the motion along F1w since 1905 occurred within a relatively narrow 9-year window between 1970 and 1979. Between 1905 and 1970, the average rate of vertical slip across F1w could not have exceeded $2.5 \mathrm{~mm} / \mathrm{yr}$, which is much lower than the average vertical rate of at least $4.3 \mathrm{~mm} / \mathrm{yr}$ observed between 1970 and 2004. Unfortunately, data limitations do not permit a determination of the temporal distribution of slip between 1905 and 1970. To illustrate this point, two scenarios of vertical slip across F1w can be considered: in one scenario, there is a negligible amount of vertical slip on F1w before 1940, $\sim 5 \mathrm{~cm}$ of coseismic slip in 1940 (similar to 1979), $\sim 9 \mathrm{~cm}$ of creep between 1940 and 1969, $\sim 9 \mathrm{~cm}$ of creep between 1970 and 1979, $\sim 5 \mathrm{~cm}$ of coseismic slip in 1979, and $\sim 2 \mathrm{~cm}$ of creep since 1979 ; in another scenario, consider $\sim 4 \mathrm{~cm}$ of creep between 1905 and 1940, $\sim 5 \mathrm{~cm}$ of coseismic slip in 1940 (again, similar to 1979), $\sim 4 \mathrm{~cm}$ of creep between 1940 and 1969, $\sim 9 \mathrm{~cm}$ of creep between 1970 and $1979, \sim 5 \mathrm{~cm}$ of coseismic slip in 1979, and $\sim 3 \mathrm{~cm}$ of creep since 1979. In the first scenario, we might infer that slip on the Imperial fault during the 1940 earthquake loaded the BFZ, but note that the fault zone has apparently slowed down since 1979. In the second scenario, the "background" creep rate is more stable over the twentieth century, the 1940 earthquake doesn't appear to be very influential, and the decade of the 1970s appears to be an anomaly. Both scenarios are equally permitted by our trenching results and by available historical data (Table 4).

By a similar reconstruction, one can constrain the amount of vertical displacement across F1w since about A.D. 1710. If unit 128 was deposited flat across $\mathrm{F} 1 \mathrm{w}$, then its upper contact has been displaced $\sim 60 \mathrm{~cm}$ across the fault, including any tilting within several meters of the fault. Because unit 128 could not have been deposited after the level of Lake Cahuilla dropped below the elevation of the trench site in about A.D. 1710 ( $\sim 33$ years after the high stand), $60 \mathrm{~cm}$ is the maximum amount of vertical displacement that could have occurred across F1w since A.D. 1710. If, however, unit 128 is older than A.D. 1710, and/or if the upper contact of unit 128 was originally higher immediately east of $\mathrm{F} 1 \mathrm{w}$, then the amount of displacement since 1710 could be less than $60 \mathrm{~cm}$. Using the cumulative slip value of $60 \mathrm{~cm}$, the highest possible average rate of vertical slip between A.D. 1710 and A.D. 1970 is $46 \mathrm{~cm}$ in 260 years, or $1.8 \mathrm{~mm} / \mathrm{yr}$; the highest possible average vertical slip rate between A.D. 1710 and A.D. 2004 is $60 \mathrm{~cm}$ in 294 years, or $2.0 \mathrm{~mm} / \mathrm{yr}$.

Finally, we can determine the vertical slip rate across F1w since the deposition of unit 95. On the downthrown side of F1w, the top of unit 95 was observed only within a meter of the fault, so we cannot be sure that we have captured in our aperture of observation all of the tilting; nonetheless, by following the deformation of overlying units, we can conservatively estimate the total vertical displacement, including tilting, of the upper contact of unit 95 to be 2.5$2.8 \mathrm{~m}$. The age of unit 95 is loosely constrained to be older than A.D. 964 (based on the A.D. $887+77 /-70$ age of the lake identified at the shoreline by Gurrola and Rockwell [1996]; see earlier discussion) but to be younger than 1368 B.C. (based on the maximum age of charcoal sample $\mathrm{C}-10$ in unit 75). The maximum, minimum, and "median" long-term vertical slip rates across $\mathrm{F} 1 \mathrm{w}$, computed using displacements of $2.8,2.5$, and $2.65 \mathrm{~m}$, and periods of 1040 , 3372 , and 2206 years, respectively, are 2.7, 0.74, and $1.2 \mathrm{~mm} / \mathrm{yr}$. Note that the minimum slip rate accounts for the possibility that unit 95 was not originally deposited horizontally across the fault: the uniform thickness across F1w of unit 80 (which is a laminated sand interpreted to have been deposited in a deltaic or meandering channel environment) implies that there was no topographic relief across F1w during or immediately after deposition of unit 80 . All apparent vertical displacement of the top of unit 95 was necessarily produced after deposition of unit 80 . As the age of unit 80 is constrained by the same charcoal sample to be younger than 1368 B.C., the possibility that unit 95 was not originally deposited horizontally does not lower the minimum vertical slip rate of $0.74 \mathrm{~mm} / \mathrm{yr}$. It is apparent from this analysis that the vertical slip rate across F1w since 1970 is significantly faster than the long-term average.

\section{Slip across Fault F1e}

Because of the section that has been removed in the vicinity of fault F1e, we have no constraints on the offsets across F1e of the youngest units. Nonetheless, we can determine the offset of the top of unit 95 across F1e. Based on the section that remains intact, the vertical offset of that contact is at least $0.5 \mathrm{~m}$, but this value is a minimum because the top of unit 95 may have been significantly higher than the base of the fill on the upthrown side of the fault. If (as we inferred earlier) unit 95 maintained its $75-\mathrm{cm}$ thickness across F1e, and if (as we also inferred) unit 80 was $90 \mathrm{~cm}$ thick immediately east of F1e, then the amount of vertical offset on the top of unit 95 across F1e would total $1.35 \mathrm{~m}$. Warping and secondary faulting in trench BFH1 East could roughly accommodate an additional $0.5 \mathrm{~m}$ of vertical separation of that contact, including $0.15 \mathrm{~m}$ on a single secondary strand $6 \mathrm{~m}$ west of F1e. To define the maximum amount of vertical offset of the top of unit 95 , we will use $1.85 \mathrm{~m}$; for the minimum vertical offset, we will use $0.65 \mathrm{~m}$ (the $0.5 \mathrm{~m}$ minimum across F1e plus the $0.15 \mathrm{~m}$ observed across the secondary fault); and for our best estimate, we will use $1.50 \mathrm{~m}$ (the inferred $1.35 \mathrm{~m}$ across F1e and the additional $0.15 \mathrm{~m}$ across the secondary fault). We will use the same time spans as in the previous paragraph for this contact. Hence, the maximum, minimum, and "median" vertical slip rates across F1e since deposition of unit 95 are 1.8, 0.19, and $0.68 \mathrm{~mm} / \mathrm{yr}$.

\section{Slip across Faults F3 and F4}

Our ability to make quantitative observations at faults F3 and F4 is severely limited, in part, because of the super- 
ficial nature of the work we did at those sites, but mostly because of the removal of a significant portion of the section there. Continuing west to east, there appears to be a slight west-side-up component to the slip at fault F3 (site BFH3 in Fig. 3), because the base of unit 100 is roughly $10-20 \mathrm{~cm}$ higher to the west (see Fig. 4e, f), but this apparent dip component of slip may be entirely the result of juxtaposition by strike-slip motion of higher topography to the west of the fault against lower topography to the east.

Farther east, at site BFH4, we identified another possible fault (F4) based partly on an apparent east-side-up step of $\sim 10 \mathrm{~cm}$ in the base of unit 100 in the wall of Mesquite Drain 2; in the agricultural field due south of this point, we observed a vegetation boundary, hereafter referred to as the "F4 vegetation boundary" (see Fig. 4g, h). We comment on the potential significance of the F4 vegetation boundary in (E) Appendix 2 in the electronic edition of BSSA. Nonetheless, we were unable to confirm whether the feature at site BFH4 is a fault. Even if it is, neither F3 nor F4 appears to have a significant vertical component of slip.

\section{Slip across Fault F2}

The series of auger boreholes dug across fault F2 allows us to place crude limits on the amount of displacement and the rate of slip across F2. As a conservative estimate, the base of unit 100 is offset vertically a minimum of $1.5 \mathrm{~m}$, based on the difference in depths to the base of unit 100 in the auger hole at the 18-m mark, and to the base of the fill in the hole at $12 \mathrm{~m}$ (see Fig. 7). As in trench BFH1 East, though, the base of unit 100 was probably higher than the present base of the fill in the hole at $12 \mathrm{~m}$. A maximum limit on the displacement of the base of unit 100 can be found by following the base of units 75-80: as long as the base of units $75-80$ is examined outside of any local channels, the amount of separation on the base of units 75-80 across F2 should be equal to or larger than the displacement of the base of unit 100. The base of units $75-80$ is $2.0 \mathrm{~m}$ lower in the hole at $18 \mathrm{~m}$ than at $12 \mathrm{~m}$; hence, the amount of discrete offset of the base of unit 100 across F2 should not exceed $2.0 \mathrm{~m}$. (Note that the hole at $12 \mathrm{~m}$ appears to be beyond the channel with its thalweg at the 4-m mark, although the 3D geometry may be more complicated than is apparent in this 2D punctuated snapshot.) Additional off-fault tilting is possible, however, because the bedding within the fault zone appears to dip slightly westward, as observed in the exposure in Mesquite Drain 2 (see Fig. 4d). By analogy to observations at faults $\mathrm{F} 1 \mathrm{w}$ and $\mathrm{F} 1 \mathrm{e}$, we estimate that tilting could accommodate up to $50 \mathrm{~cm}$ of additional slip. For our maximum, minimum, and "median" limits on the amount of offset of the base of unit 100 across F2, we will use 2.5, 1.5, and $2.0 \mathrm{~m}$, respectively; we will use the same time spans as for fault $\mathrm{F} 1 \mathrm{w}$ and F1e. Hence, the respective maximum, minimum, and "median" vertical slip rates across F2 are 2.4, 0.44 , and $0.91 \mathrm{~mm} / \mathrm{yr}$.

\section{Slip Rate across the Entire BFZ}

A list of the slip rates that we can determine across each strand, over various intervals, is given in Table 5. We can compute the maximum, minimum, and best estimates of the long-term vertical slip rate across every strand based on the unit 95/100 contact. Adding the amounts of slip constrained on F1w, F1e, and F2, and ignoring the presumably small contributions from F3, F4, and any unrecognized faults, we have a total vertical offset of that contact of between $4.65 \mathrm{~m}$ and $7.15 \mathrm{~m}$, with a best estimate of $6.15 \mathrm{~m}$. Using the age limits discussed earlier, we calculate a preferred vertical slip rate of $2.8 \mathrm{~mm} / \mathrm{yr}$, with possible values in the range 1.4$6.9 \mathrm{~mm} / \mathrm{yr}$. Between 1970 and 1979, $8.9 \mathrm{~cm}$ of vertical creep (excluding 1979 coseismic slip) was documented, for a short-term vertical creep rate of $10 \mathrm{~mm} / \mathrm{yr}$. The vertical slip rate between 1970 and 1979 was significantly higher than the long-term rate, both across F1w and across the entire BFZ at Harris Road. Between 1970 and 2004, a minimum of $24.1 \mathrm{~cm}$ of vertical slip occurred across the entire BFZ at Harris Road, but this value may underestimate the actual value by a significant factor. Using the minimum slip value, the average vertical slip rate between 1970 and 2004 must be at least $7.2 \mathrm{~mm} / \mathrm{yr}$, or more than twice the preferred longterm rate (Table 5).

\section{Evidence for Events}

As mentioned earlier, we will not attempt to determine the number of events recorded in our trenches on the BFZ. Nonetheless, we will now list, in brief, the evidence we were able to document for events at various horizons. At the top of unit 128 (base of unit 140) in trench BFH1 West, multiple abrupt fault terminations and filled-in fissures suggest that an event or series of events occurred after deposition of unit 128 but prior to deposition of unit 140 (the most prominent fissure is filled in by unit 140a); additional evidence comes from the observation that the vertical separation across the fault of the top of unit 128 is greater than the separation of any overlying unit (note that units 140-156 constitute a thin growth section). As an aside, the unit 128 sand appears to be deformed in a brittle manner, suggesting that these (and all subsequent events) occurred under subaerial conditions, when the ground was not saturated; in other words, Lake Cahuilla had already desiccated to below this elevation by the time these earthquakes occurred. This observation is consistent with the inferred depositional environments of all stratigraphy above unit 130 .

In addition to the events at the top of unit 128 , significant offset of units 116 and below, coupled with a thick growth section (units 120-128) on the downdropped side of fault F1w, suggests that an event or series of events occurred during the course of the deposition of units 100-116 and/or soon thereafter. At the top of unit 95 (base of unit 100) in trench BFH1 East, multiple abrupt fault terminations and filled-in fissures (especially the fissure in the secondary fault 
Table 5

Vertical Slip Rates along the Brawley Fault Zone at Harris Road*

\begin{tabular}{|c|c|c|c|c|}
\hline \multirow[b]{2}{*}{ Time Window and Type } & \multicolumn{3}{|c|}{ Fault Strand } & \multirow[b]{2}{*}{ Total } \\
\hline & F1w & Fle & F2 & \\
\hline $\begin{array}{l}\text { Long-term }{ }^{\dagger} \\
\text { (from base of unit 100) }\end{array}$ & $\begin{array}{c}1.2 \\
(0.74-2.7)\end{array}$ & $\begin{array}{c}0.68 \\
(0.19-1.8)\end{array}$ & $\begin{array}{c}0.91 \\
(0.44-2.4)\end{array}$ & $\begin{array}{c}2.8 \\
(1.4-6.9)\end{array}$ \\
\hline $\begin{array}{l}\text { A.D. } 1710-1970 \text { (maximum) } \\
\quad \text { (from top of unit 128) }\end{array}$ & 1.8 & & & \\
\hline $\begin{array}{l}\text { A.D. } 1710-2004 \text { (maximum) } \\
\text { (from top of unit 128) }\end{array}$ & 2.0 & & & \\
\hline $\begin{array}{l}\text { A.D. } 1905-1970 \text { (maximum) } \\
\quad \text { (from units } 158-160)\end{array}$ & 2.5 & & & \\
\hline $\begin{array}{l}\text { A.D. } 1905-2004 \text { (maximum) } \\
\quad \text { (from units } 158-160)^{\ddagger}\end{array}$ & 3.0 & & & \\
\hline $\begin{array}{l}\text { A.D. } 1970-1979 \text { creep } \\
\quad \text { (excluding } 1979 \text { coseismic slip) }\end{array}$ & 10 & 0.1 & 0 & 10 \\
\hline $\begin{array}{l}\text { A.D. } 1970-2004 \text { (minimum) }^{\S} \\
\quad \text { (including coseismic slip) }\end{array}$ & 4.3 & 0.77 & 2.1 & 7.2 \\
\hline
\end{tabular}

*Slip rates shown in this table are in millimeters per year and include slip measured within several meters of each fault zone; broad tilting or warping beyond this distance is not considered. In this manner the data in this table are comparable to data presented in Table 4. Lateral slip rates have not been determined. See text for discussion of the calculation of these rates.

The long-term rates are determined from inferred offsets of the base of unit 100 across each fault strand and include slip to A.D. 2004. Shown in this row are the preferred rates across each strand, as well as the allowable rates (stated as a range of numbers in parentheses) given the uncertainties in slip and age discussed in the text. The long-term rate is averaged over the past 1 to 3 millennia.

*The values shown in this row are maximum average rates permitted by the data for the given period; average vertical rates may be less than the stated value.

${ }^{\S}$ The values shown in this row are minimum average rates permitted by the data for the given period; average vertical rates may be more than the stated value.

strand $6 \mathrm{~m}$ west of F1e; see Fig. 6, and (E) supplemental Fig. 2 in the electronic edition of BSSA) suggest that a moderate event, perhaps as large as 1979 or larger, occurred after deposition of unit 95 but before deposition of unit 100. Finally, note that there appear to be at least two generations of fault strands within the main F1e fault zone (see Fig. 6, and (E) supplemental Fig. 2 in the electronic edition of BSSA). The faults in blue on supplemental Figure 2 (which are inferred to be the older generation) appear to have been tilted (along with the stratigraphy, to which the blue faults are still roughly perpendicular) by a younger generation of faults, namely those faults in red.

It is tempting to suggest, based on historical evidence, that creep along the BFZ at Harris Road mostly manifests along fault F1w, and that the other fault strands are only activated during coseismic ruptures. However, with data reliable enough to answer this question covering only the period since the road was paved in 1970, such a suggestion is little more than speculation. Alternatively, coseismic slip in 1940 may have occurred almost exclusively on F2, and the creep that has occurred more recently may be restricted to F1w, because the latter fault strand is "catching up."

\section{Discussion}

This study documents evidence for a long-term vertical slip rate of $2.8(+4.1 /-1.4) \mathrm{mm} / \mathrm{yr}$ across the oblique-slip
BFZ at Harris Road. Despite the considerable uncertainty in this rate, it is lower than both the average modern vertical rate (since 1970) and the vertical creep rate (excluding coseismic slip) during the 1970s. It is slightly lower than the 4-8 mm/yr subsidence rate predicted for Mesquite Basin by Smith and Sandwell (2003, 2006), and it is about the same as the subsidence rate determined by Larsen and Reilinger (1991), although, as discussed earlier, Larsen and Reilinger's (1991) rate should only be construed as a minimum. It is possible that we have missed some minor strands of the BFZ in our investigation of prehistoric slip, but, given our ability to follow the stratigraphy along most of the agricultural drain that crosses the BFZ just south of Harris Road, it is unlikely that we are missing any fault strands with a substantial amount of prehistoric dip slip. Two possible interpretations of the lower rate across the BFZ proper, in contrast to the subsidence rate of Smith and Sandwell $(2003,2006)$, are (1) that some permanent strain is taken up at the surface as highly diffuse off-fault tilting or warping over tens to hundreds of meters, or (2) that the strike-slip rates inferred by Smith and Sandwell $(2003,2006)$ for the southern San Andreas, Brawley, and Imperial faults are too high, yielding an overestimate of the subsidence rate.

If modern behavior is any indicator (in terms of the ratio of horizontal to vertical components of slip), then the longterm rate of strike slip across the BFZ should be lower than the long-term rate of vertical slip, at least in the vicinity of 
Harris Road. The long-term vertical slip rate, and hence (following this logic) the long-term strike-slip rate, is considerably lower than estimates of the strike-slip rates on the SAF in the Indio Hills $(\geq 16 \mathrm{~mm} / \mathrm{yr}$ based on Pleistocene alluvial fan offsets [van der Woerd et al., 2006]) or the Imperial fault at the International Border (15-20 mm/yr based on slip in 1940 and the time between the last two large events [Thomas and Rockwell, 1996]), both of which feed into the BFZ. However, evidence suggests that the vertical-to-lateral slip ratio may vary considerably over time: as Sharp (1982) observed, in some localities on the Imperial fault and in the BFZ, the ratio of vertical to horizontal components of slip for the 1979 displacement differed substantially from those for other displacements from 1940 to present. Additionally, the model of Smith and Sandwell $(2003,2006)$ predicts that the subsidence rate of Mesquite Basin will be only a fraction of the strike-slip rates on the southern San Andreas, Brawley, and Imperial faults. Nonetheless, the rate of vertical slip observed historically is not representative of the average vertical rate over the past century and longer, and to the extent to which the vertical slip rate is proportional to the net rate of slip, the same contrast can be made for overall slip.

The escalation in the vertical slip rate in recent decades raises several intriguing questions. Has seismicity in the BSZ and in the vicinity of Mesquite Basin also seen an increase in the past few decades, in comparison with rates earlier in the twentieth century? Unfortunately, this is difficult to determine, as the region was poorly instrumented prior to 1973 (Johnson and Hill, 1982). Has strain accumulation increased over these timescales? Again, this is not possible to answer at present, because the geodetic network is too young. Finally, could the increased slip along the BFZ be loading the southernmost SAF at a faster rate, or could it be a signal that the southernmost SAF is closer now to some critical stress threshold than it has been for the past few centuries? Either way, the escalation of slip along the BFZ may have important and far-reaching implications: the southernmost SAF has not sustained a major rupture in three centuries, it is highly stressed (Smith and Sandwell, 2006), and many have speculated that it will be the next segment of the SAF to fail.

\section{Conclusions}

Our study suggests, across the westernmost strand of the BFZ and across the entire BFZ at Harris Road, that both the average vertical slip rate observed in modern times (since 1970) and the vertical creep rate (excluding coseismic slip) observed during the 1970s are significantly higher than the long-term average. Across the westernmost strand, the longterm vertical rate is $1.2(+1.5 /-0.5) \mathrm{mm} / \mathrm{yr}$, and the average rate since about A.D. 1710 is determined to be no greater than $2.0 \mathrm{~mm} / \mathrm{yr}$; in contrast, the average vertical rate between 1970 and 2004 across that strand was at least $4.3 \mathrm{~mm} / \mathrm{yr}$, and the 1970s aseismic creep rate was $10 \mathrm{~mm} / \mathrm{yr}$. Likewise, across the entire BFZ, the long-term vertical rate is 2.8 $(+4.1 /-1.4) \mathrm{mm} / \mathrm{yr}$, whereas the rate between 1970 and
2004 was at least $7.2 \mathrm{~mm} / \mathrm{yr}$, and the 1970s aseismic creep rate was $10 \mathrm{~mm} / \mathrm{yr}$. Unfortunately, the long-term strike-slip rate cannot be determined across any strands of the BFZ but may be significant. In contrast to the high-sedimentation rates suggested by Van de Kamp (1973) for the entire Imperial Valley, we calculate that the average sedimentation rate on the downthrown side of the BFZ in the Mesquite Basin, in the millennium preceding the onset of agricultural influences, was at the most $3.5 \mathrm{~mm} / \mathrm{yr}$.

\section{Acknowledgments}

We thank the many people who have been directly and indirectly involved with this project. First, we express our gratitude to the Imperial Irrigation District for granting us access to the site. Foremost, we thank Majdi Barjous, Chris Madden, Chris Lynch, Danielle Verdugo, Faten Khatib, and Chris Walls for field assistance, including help in hand-excavating and deepening parts of the trench, help in etching contacts and photographing the walls, and help in surveying, and also for offering valuable feedback and sanity during the hot summer days in the Imperial Valley. We are indebted to Mark Osterkamp for his friendly conversations and his eagerness to help us, for sharing his knowledge of the land, and for bringing to our attention the existence of several early surveyors' maps. We also thank Charles Lovett of the Imperial County Surveyor's Office for offering his assistance and providing us with copies of those early maps. We thank Daniel Ragona and Jeri Young for thoughtful suggestions and feedback, and Clarence Allen for providing unpublished material and helpful advice. We are grateful to Michael Rymer for his assistance in searching through boxes of unpublished leveling data, and to Gordon Seitz for speedy results in the analysis of our radiocarbon samples. Finally, we thank Sally McGill and Heidi Stenner for excellent reviews that led to substantial improvements of this article. This project was funded by U.S. Geological Survey grant 03HQGR0017.

\section{Note Added in Proof}

In the late stages of publication of this article, we became aware of an additional prehistoric Lake Cahuilla highstand that has been recognized in the Salton Trough. The unpublished date comes from a $+13-\mathrm{m}$ elevation Lake Cahuilla shoreline site near Siphon 15 on the Coachella Canal, east of Frink on the east shore of the Salton Sea. The dated sample was of a peat lens within a lagoonal silt deposit that directly underlies an old gravelly beach berm. The sample, collected and dated in 1986, yielded an uncalibrated ${ }^{14} \mathrm{C}$ age of $2500 \pm 60$ radiocarbon years B.P., which corresponds to a calibrated calendric $2 \sigma$ date range of 791-415 B.C. (S. McGill, unpublished data, 1986, and personal comm., 2006.)

If the sample accurately dates a Lake Cahuilla highstand, and if units $100-130$ in our trenches represent all the lakes within the past 3200 years that filled the Salton Trough to an elevation of $-36 \mathrm{~m}$ or higher, as argued in our article, then the 791-415 B.C. lake must also be included in those units. This would push back the age of the base of unit 100 toward the older end of its possible age range (to 1368-415 B.C.), and that would imply both a slower sedimentation rate over the past few millennia and a longterm vertical slip rate that was closer to the low end of our allowed range. In particular, the long-term vertical slip rate across strand $\mathrm{F} 1 \mathrm{w}$ would be $0.74-1.2 \mathrm{~mm} / \mathrm{yr}$, across F1e would be $0.19-0.76 \mathrm{~mm} / \mathrm{yr}$, across F2 would be $0.44-1.0 \mathrm{~mm} / \mathrm{yr}$, and across the entire BFZ at Harris Road would be 1.4 $3.0 \mathrm{~mm} / \mathrm{yr}$; the preferred rate across the entire BFZ would be $6.15 \mathrm{~m}$ of vertical slip in 2896 years, or $2.1 \mathrm{~mm} / \mathrm{yr}$. The average sedimentation rate over the past two millennia or more would be no more than $1.5 \mathrm{~mm} / \mathrm{yr}$. Once again, however, we cannot preclude the possibility that all of our radiocarbon and OSL dates are too old, that the 791-415 B.C. lake of S. McGill is represented at the BFZ Harris Road sites by units $60-62$ or 
lower, and that units 100-130 are considerably younger than the 791-415 B.C. lake.

\section{References}

Adamiec, G., and M. J. Aitken (1998). Dose-rate conversion factors: update, Ancient TL 16, 37-50.

Aitken, M. J. (1998). An Introduction to Optical Dating: The Dating of Quaternary Sediments by the Use of Photon-Stimulated Luminescence, Oxford University Press, New York, 267 pp.

Barrows, D. P. (1900). The Colorado Desert, Natl. Geogr. Mag. 11, $337-$ 351.

Blake, W. P. (1854). Ancient lake in the Colorado Desert, Am. J. Sci. (second series) 17, 435-438.

Blake, W. P. (1915). Sketch of the region at the head of the Gulf of California, in The Imperial Valley and the Salton Sink, H. T. Cory (Editor), J. J. Newbegin, San Francisco, California, 1-35.

Cohn, S. N., C. R. Allen, R. Gilman, and N. R. Goulty (1982). Preearthquake and postearthquake creep on the Imperial fault and the Brawley fault zone, in The Imperial Valley, California, Earthquake of October 15, 1979, U.S. Geol. Surv. Profess. Pap. 1254, 161-167.

Cory, H. T. (1913). Irrigation and river control in the Colorado River Delta, Trans. ASCE 76, 1204-1453, paper no. 1270. Reprinted in Cory, H. T. (1915). The Imperial Valley and the Salton Sink, J.J. Newbegin, San Francisco, California, $452 \mathrm{pp}$.

Emory, W. H. (1848). Notes of a Military Reconnoissance [sic] from Fort Leavenworth, in Missouri, to San Diego, in California, including parts of the Arkansas, Del Norte, and Gila Rivers, Wendell and Van Benthuysen, Washington, D.C., 416 pp.

Fuis, G. S., W. D. Mooney, J. H. Healey, G. A. McMechan, and W. J. Lutter (1982). Crustal structure of the Imperial Valley region, in The Imperial Valley, California, Earthquake of October 15, 1979, U.S. Geol. Surv. Profess. Pap. 1254, 25-49.

Goulty, N. R., R. O. Burford, C. R. Allen, R. Gilman, C. E. Johnson, and R. P. Keller (1978). Large creep events on the Imperial fault, California, Bull. Seism. Soc. Am. 68, 517-521.

Gurrola, L. D., and T. K. Rockwell (1996). Timing and slip for prehistoric earthquakes on the Superstition Mountain fault, Imperial Valley, southern California, J. Geophys. Res. 101, 5977-5985.

Hays, J. C. [U.S. Surveyor General, California] (1856a). Map of Township No. 14 South, Range No. 14 East, San Bernardino Meridian, scale 1:35,000 (surveyed in 1854-1856).

Hays, J. C. [U.S. Surveyor General, California] (1856b). Map of Township No. 14 South, Range No. 15 East, San Bernardino Meridian, scale 1:35,000 (surveyed in 1854-1856).

Hays, J. C. [U.S. Surveyor General, California] (1856c). Map of Township No. 15 South, Range No. 14 East, San Bernardino Meridian, scale 1:35,000 (surveyed in 1854-1856).

Hays, J. C. [U.S. Surveyor General, California] (1856d). Map of Township No. 15 South, Range No. 15 East, San Bernardino Meridian, scale 1:35,000 (surveyed in 1854-1856).

Johnson, C. E., and D. M. Hadley (1976). Tectonic implications of the Brawley earthquake swarm, Imperial Valley, California, January 1975, Bull. Seism. Soc. Am. 66, 1133-1144.

Johnson, C. E., and D. P. Hill (1982). Seismicity of the Imperial Valley, in The Imperial Valley, California, Earthquake of October 15, 1979, U.S. Geol. Surv. Profess. Pap. 1254, 15-24.

Johnson, H. O., D. C. Agnew, and F. K. Wyatt (1994). Present-day crustal deformation in southern California, J. Geophys. Res. 99, 23,95123,974 .

Keller, B. (1979). Structure of the Salton Trough from gravity and seismic refraction data, in Tectonics of the Juncture between the San Andreas Fault System and the Salton Trough, Southeastern California, J. C. Crowell and A. G. Sylvester (Editors), Geol. Soc. Am. Field Trip Guidebook, 57-64.
Larsen, S., and R. Reilinger (1991). Age constraints for the present fault configuration in the Imperial Valley, California: evidence for northwestward propagation of the Gulf of California rift system, J. Geophys. Res. 96, 10,339-10,346.

Louie, J. N., C. R. Allen, D. C. Johnson, P. C. Haase, and S. N. Cohn (1985). Fault slip in southern California, Bull. Seism. Soc. Am. 75, 811-833.

McGill, S. F., C. R. Allen, K. W. Hudnut, D. C. Johnson, W. F. Miller, and K. E. Sieh (1989). Slip on the Superstition Hills fault and on nearby faults associated with the 24 November 1987 Elmore Ranch and Superstition Hills earthquakes, southern California, Bull. Seism. Soc. Am. 79, 362-375.

Meckel, L. D. (1972). Anatomy of distributary channel-fill deposits in recent mud deltas, Am. Assoc. Petrol. Geol. Bull. 56, 639.

Mejdahl, V. (1979). Thermoluminescence dating: beta-dose attenuation in quartz grains, Archaeometry 21, 61-73.

Modesto, R., and G. Mount (1980). Not for Innocent Ears: Spiritual Traditions of a Desert Cahuilla Medicine Woman, Sweetlight Books, Arcata, California, $120 \mathrm{pp}$.

Murray, A. S., and A. G. Wintle (2000). Luminescence dating of quartz using an improved single-aliquot regenerative-dose protocol, Radiat. Meas. 32, 57-73.

Nicholson, C., L. Seeber, P. Williams, and L. Sykes (1986). Seismic evidence for conjugate slip and block rotation within the San Andreas fault system, southern California, Tectonics 5, 629-648.

Orgil, A. (2001). Three-dimensional paleoseismic investigation on the south break of the Coyote Creek fault, southern California, M.S. Thesis, San Diego State University, San Diego, California, 85 pp.

Prescott, J. R., and J. T. Hutton (1994). Cosmic-ray contributions to doserates for luminescence and ESR dating: large depths and long-term time variations, Radiat. Meas. 23, 497-500.

Prescott, J. R., and L. G. Stephan (1982). The contribution of cosmic radiation to the environmental dose for thermoluminescent dating; latitude, altitude and depth dependences. PACT 6, 17-25.

Ragona, D. (2003). A high resolution paleoseismic study in the southern San Jacinto fault zone, Imperial Valley, California, M.S. Thesis, San Diego State University, San Diego, California, 95 pp.

Rockwell, T. K., and K. Sieh (1994). Correlation of large earthquakes using regional lacustrine stratigraphy, examples from the Salton Trough, California, Geol. Soc. Am. Abstr. Programs 26, A-239.

Rymer, M. J., J. Boatwright, L. C. Seekins, J. D. Yule, and J. Liu (2002). Triggered surface slips in the Salton Trough associated with the 1999 Hector Mine, California, earthquake, Bull. Seism. Soc. Am. 92, 13001317.

Sharp, R. V. (1976). Surface faulting in Imperial Valley during the earthquake swarm of January-February, 1975, Bull. Seism. Soc. Am. 66, $1145-1154$.

Sharp, R. V. (1977). Map showing Holocene surface expression of the Brawley fault, Imperial County, California, U.S. Geol. Surv. Misc. Field Studies Map MF-838, scale 1:24,000.

Sharp, R. V. (1982). Comparison of 1979 surface faulting with earlier displacements in the Imperial Valley, in The Imperial Valley, California, Earthquake of October 15, 1979, U.S. Geol. Surv. Profess. Pap. 1254, 213-221.

Sharp, R. V. (1989). Pre-earthquake displacement and triggered displacement on the Imperial fault associated with the Superstition Hills earthquake of 24 November 1987, Bull. Seism. Soc. Am. 79, 466-479.

Sharp, R. V., and J. J. Lienkaemper (1982). Preearthquake and postearthquake near-field leveling across the Imperial fault and the Brawley fault zone, in The Imperial Valley, California, Earthquake of October 15, 1979, U.S. Geol. Surv. Profess. Pap. 1254, 169-182.

Sharp, R. V., J. J. Lienkaemper, M. G. Bonilla, D. B. Burke, B. F. Fox, D. G. Herd, D. M. Miller, D. M. Morton, D. J. Ponti, M. J. Rymer, J. C. Tinsley, J. C. Yount, J. E. Kahle, E. W. Hart, and K. Sieh (1982). Surface faulting in the central Imperial Valley, in The Imperial Valley, California, Earthquake of October 15, 1979, U.S. Geol. Surv. Profess. Pap. 1254, 119-143. 
Sharp, R. V., M. J. Rymer, and J. J. Lienkaemper (1986). Surface displacement on the Imperial and Superstition Hills faults triggered by the Westmorland, California, earthquake of 26 April 1981, Bull. Seism. Soc. Am. 76, 949-965.

Sieh, K. E. (1986). Slip rate across the San Andreas and prehistoric earthquakes at Indio, California, EOS Trans. AGU 67, 1200.

Sieh, K. E., and P. L. Williams (1990). Behavior of the southernmost San Andreas fault during the past 300 years, J. Geophys. Res. 95, 66296645 .

Smith, B., and D. Sandwell (2003). Coulomb stress accumulation along the San Andreas fault system, J. Geophys. Res. 108, no. B6, 2296, doi 10.1029/2002JB002136.

Smith, B. R., and D. T. Sandwell (2006). A model of the earthquake cycle along the San Andreas fault system for the past 1000 years, J. Geophys. Res. 111, B01405, doi 10.1029/2005JB003703.

Stanley, G. M. (1963). Prehistoric lakes in the Salton Sea Basin, Spec. Pap. Geol. Soc. Am. 73, 249-250.

Stanley, G. M. (1966). Deformation of Pleistocene Lake Cahuilla shoreline, Salton Basin, California, Spec. Pap. Geol. Soc. Am. 87, 165 pp.

Stuiver, M., and H. A. Polach (1977). Discussion: reporting of C-14 data, Radiocarbon 19, 355-363.

Stuiver, M., and P. J. Reimer (1993). Extended ${ }^{14} \mathrm{C}$ database and revised CALIB 3.0 ${ }^{14} \mathrm{C}$ age calibration program, Radiocarbon 35, 215-230.

Stuiver, M., P. J. Reimer, E. Bard, J. W. Beck, G. S. Burr, K. A. Hughen, B. Kromer, G. McCormac, J. van der Plicht, and M. Spurk (1998). INTCAL98 radiocarbon age calibration, 24,000-0 cal BP, Radiocarbon 40, 1041-1083.

Sykes, G. (1937). The Colorado Delta, Carnegie Inst. Washington Publ. 460 and Amer. Geographical Soc. Spec. Publ. 19, 193 pp.

Thomas, A. P., and T. K. Rockwell (1996). A 300-550-year history of slip on the Imperial fault near the U.S.-Mexico border: Missing slip at the Imperial fault bottleneck, J. Geophys. Res. 101, 5987-5997.

Thomas, R. G. (1963). The late Pleistocene 150-foot fresh water beachline of the Salton Sea area, S. Calif. Acad. Sci. Bull. 62, 9-17.
U.S. Geological Survey (USGS) (1907). Holtville Quadrangle, California, 30 ' topographic map (surveyed 1905), scale 1:125,000.

U.S. Geological Survey (USGS) (1908). Reconnaissance Map of the Salton Sink, California, scale 1:500,000.

Van de Kamp, P. C. (1973). Holocene continental sedimentation in the Salton Basin, California: a reconnaissance, Geol. Soc. Am. Bull. 84, $827-848$.

van der Woerd, J., Y. Klinger, K. Sieh, P. Tapponnier, F. J. Ryerson, and A.-S. Mériaux (2006). Long-term slip rate of the southern San Andreas fault from ${ }^{10} \mathrm{Be}-{ }^{26} \mathrm{Al}$ surface exposure dating of an offset alluvial fan, J. Geophys. Res. 111, B04407, doi 10.1029/2004JB003559.

Waters, M. R. (1983). Late Holocene lacustrine stratigraphy and archaeology of ancient Lake Cahuilla, California, Quat. Res. 19, 373-387.

Working Group on California Earthquake Probabilities (1995). Seismic hazards in southern California: probable earthquakes, 1994 to 2024, Bull. Seism. Soc. Am. 85, 379-439.

Department of Geological Sciences

San Diego State University

San Diego, California 92182

meltzner@gps.caltech.edu

trockwell@geology.sdsu.edu

(A.J.M., T.K.R.)

Department of Geology

University of Cincinnati

Cincinnati, Ohio 45221-0013

lewis.owen@uc.edu

(L.A.O.)

Manuscript received 14 November 2005. 